\title{
Brain injuries in boxing and soccer: a neuropsychological approach
}

Citation for published version (APA):

Matser, J. T. (2000). Brain injuries in boxing and soccer: a neuropsychological approach. [Doctoral Thesis, Maastricht University]. Universiteit Maastricht. https://doi.org/10.26481/dis.20000705jm

Document status and date:

Published: 01/01/2000

DOI:

10.26481/dis.20000705jm

Document Version:

Publisher's PDF, also known as Version of record

\section{Please check the document version of this publication:}

- A submitted manuscript is the version of the article upon submission and before peer-review. There can be important differences between the submitted version and the official published version of record.

People interested in the research are advised to contact the author for the final version of the publication, or visit the DOI to the publisher's website.

- The final author version and the galley proof are versions of the publication after peer review.

- The final published version features the final layout of the paper including the volume, issue and page numbers.

Link to publication

\footnotetext{
General rights rights.

- You may freely distribute the URL identifying the publication in the public portal. please follow below link for the End User Agreement:

www.umlib.nl/taverne-license

Take down policy

If you believe that this document breaches copyright please contact us at:

repository@maastrichtuniversity.nl

providing details and we will investigate your claim.
}

Copyright and moral rights for the publications made accessible in the public portal are retained by the authors and/or other copyright owners and it is a condition of accessing publications that users recognise and abide by the legal requirements associated with these

- Users may download and print one copy of any publication from the public portal for the purpose of private study or research.

- You may not further distribute the material or use it for any profit-making activity or commercial gain

If the publication is distributed under the terms of Article $25 \mathrm{fa}$ of the Dutch Copyright Act, indicated by the "Taverne" license above, 


\title{
Brain injuries in boxing and soccer:
}

\section{a neuropsychological approach}

\author{
Proefschrift
}

ter verkrijging van de graad van doctor aan de Universiteit Maastricht

op gezag van de Rector Magnificus,

Prof A.C. Nieuwenhuizen Kruzeman

volgens het besluit van het College van Decanen, in het openbaar te verdedigen,

op woensdag 5 juli 2000 om 14.00 uur

door

Johannes Theodorus Matser

geboren op 29 maart 1963 te Zevenaar 


\section{Promotor}

Prof. Dr J Troost

\section{Co-promotor}

Dr. M.D. Lezak (Oregon Health Sciences University, Portand OR, USA)

\section{Beoordelingscommissie}

Ptof. dr. J. Jolles (voorzitter)

Prof. dr. E.H.F. dle Haan (Universiteit Utrecht)

Prof. dr. M.A. van den Hout

Prof, dr. G.W.A.M. Padberg (Katholieke Universiteit Nijmegen)

Dr. A. Twijnstra

Financial support for this publication was gratefully received from:

St. Anna Ziekenhuis Geldrop

Bureau Pals

Rabobank Geldrop 
Niets immers kan mij bet leven vergoeden, niet al wat aan rijkdom, naar wordt verteld, bet bezit is geweest van bet prachtige Troje, vroeger in dagen van vrede, nog voor de komst van de Grieken, noch wat de tempel van Foibos Apollo, de feilloze schutter, acbter zijn stenen drempel verbergt, in bet rotsachtige Python. Meester kan men zich maken van runderen en vlezige schapen en bet bezit van ketels en rosbruine paarden verkrijgen, maar bet leven kan men door koop noch door roof zich verwerven; 't keert niet terug, nadat bet de beining der tanden ontsnapt is.

Mij beeft mijn moeder verteld, de zilvervoetige Thetis, dat me bet noodlot langs tweeërlei wegen bet eind van de dood brengt: als ik bier voortga de strijd om de stad der Trojanen te voeren, valt me geen thuiskomst ten deel, maar wel onsterfelijke krijgsroem; als daarentegen ik naar mijn vaderland weerkeer, valt me geen krijgsroem te beurt, maar wel, tot in lengte van jaren, zal ik bet leven bebouden en niet de dood mij verrassen

(Illias, boek negen) 


\author{
Ter nagedachtenis aan \\ Cor Kanters, de vader van Marly, \\ een vader die te weinig jaren heeft gekregen.
}

Opgedragen aan:

Marly, Lize, Rolf en Myré, de kleuren van mijn leven. 


\section{Contents}

Aim of the study

1 Introduction

2 Acute traumatic brain injury in amateur boxing

3 Neuropsychological impairmen in amateur boxers

4 Neuropsychological impairment in amateur soccer players

48

5 Chronic traumatic brain injury in professional soccer players 57

6 Contribution of headers and soccer related concussions to cognitive impairment in professional soccer players

General comment

Summary

Samenvatting

Dankwoord 



\section{Aim of the study}

Head injuries are not uncommon in many sports. However, few sports include blows to the head or with the head as part of the accepted way of playing the game and boxing in particular of winning. Our growing knowledge concerning the detrimental effects on cognitive functioning of blows to the head especinlly of repeated blows to the head raises serious questions about the cognitive consequences of deliberately inflicting repeated blows to one"s own head (i.e., doing headers in soccer) or to the opponents head (i.e., striving for a knock out in boxing). Since many young people throughout the world engage in these two sports, it is important to find out whether their participation in these sports can adversely affect their mental abilities in the present and for their futures. The aim of these studies has been to determine whether athletes risk cognitive impairment when they participate in sports in which blows to the head are an integral part of the game.

\section{Background of the study}

In recent years, brain injuries in athletes have captured many news headlines as several elite athletes have retired due to the effects of concussion. Depending on the nature of the sport these injuries are many times viewed as just part of the game. While many of these injuries are minor, some can be quite serious with long term consequences.

In 1928 an American neurologist published a paper in which he described a peculiar condition in prize fighters. Martland documented abnormal emotional responses, motor abnormalities and severe cognitive problems in relatively young people. In 1969 Johnson copied his research and reported that $20 \%$ of the professional boxing population he studied showed dementia pugilistica. MRI studies performed in the 90 's showed brain abnormalities in $45 \%$ of professional boxers and in the 80 's and 90 's several studies showed that $90 \%$ of the professional boxing population showed mild to severe cognitive problems. Besides boxing noncontact and collision sports were studied concerning the risk for traumatic brain injury and cognitive impairments. Tysvaer demonstrated in Norway that $33 \%$ of retired amateur soccer players showed ventricular dilation and a high percentage $(81 \%)$ of these players demonstrated memory problems compared to age matched controls. Most of these studies published were retrospective. 
In 1993 in Americt, the Pittsburgh Steelers project was the first long term followup project in which athletes (Amenican football players) were followed during several geasons. This study involved systematic testing of athletes at set times. Formal ewaluation of each player prior to the beginning of the season provided the basis for comparison in the event of a concussion during the season. Testing was repeated 24 hours after a suspected concussion, and again approximately five days after injury. "The study showed memory complaints after concussion in athletes and that $15 \%$ of the athletes showed these problems longer than a year. After this study was carried out the Quality Standards Committee of the American Academy of Neurology (AN) developed in 1997 a formal practice parameter for the management of concussion in sports. These guidelines included recommendations for the development of a valid, standardized sideline evaluation for the immediate assessment of concussion in athletes.

Momentarily a sideline assessment of concussion is developed in the Netherlands focused on soccer. In the USA guidelines are recommended to protect American football/ ice hockey players after an acute traumatic brain injury.

\section{Relevance of the study}

A main problem in the diagnosis of acute MTBI is that both CT" and MRI show no abnormalities in athletes and patients with these traumas as evaluations of MRI scans of amateur boxers directly after a knock out showed. Even in demonstrating chronic brain trauma, CT and MRI scanning techniques have limited value. Post traumatic atrophy can be detected by MRT and CT, especially in athletes with dementia pugilistica, but at the time the motphological abnormality is detected the athlete suffers already profound cognitive impaiments. The introduction of neuropsychological assessment has made it possible to demonstrate subtle cognitive impaiments due to MTBL. These findings are important because we will be able to identify brain injury earlier and more accurate. Neuropsychological assessment should add to our ability to identify athletes at risk for MTBI and the future development of more severe brain injury. In addition, neuropsychological assessment can be a very sensitive tool in detecting acute and the development of chronic traumatic brain injury in athletes. Finally, according to scores on neuropsychological tests retum to play decisions can be made. 


\section{Chapter 1}

\section{Introduction*}

J.T. Matser Msc

* Modified from: Matser JT. Sportsneuropsychology. In: Jordan BD, Tsairis P, Warren RF, Eds. Sportsneurology, 2nd edition. Philidelphia-New York:

Lippincott - Raven, $1998 ; 15 \% 2 \%$. 


\section{Summary}

The studies represented in this dissertation are an attempt to describe and explain the many difficult issues that exist regarding diagnosis and outcome of sports related concussion, acute traumatic brain injury (ATBN) and chronic traumatic brain injury (CTBI).

In recent years, sportsneurological injuries have captured attention as several professional football-, hockey-and soccer players have tetired due to the effects of sports related traumatic brain injury. Even in the amateur section millions of people sustain one or mote sports.related traumatic brain injuries each year, causing mild to severe impairments. In cypical contact- and collision sports like boxing, American football and soccer these injuries frequenty occur.

Single sports-related TBI can result in neurologic- and cognitive deficits. Cumulations of sports related TBI in an extended period (weeks, months) can result in aggravation of neurologic- and cognitive symptoms. Repeated mild brain injuties occuring within a short period (i.e., minutes) can have dramatic effects regarding cognitive functioning and can be life threatening (diffuse cerebral brain swelling, second impact syndrome). Therefore, early detection through a thorough knowledge of symptoms and specific documentation of the injury is critical to the management of sports related traumatic brain injury.

Most of the impairments documented in our studies of contact-and collision sports athletes are in the cognitive domains like memory, planning, visuo perception, attention and concentration. However, at the end of this century and at the beginning of a new millennium there is still a lot of work to do for designing areas of agreement and disagreement in the detection and management of sports related traumatic brain injury.

\section{Introduction}

Recreational, amateur, and professional sports occupy a high level of importance in present day European- and American society. The motivation to participate in contact or collision sports increases the risk for incurring all kinds of injuries. This is especially significant when one considers traumatic brain injuries (TBD) and a variety of other disabling neurological injuries. Although the majority of the neurological injuries tend to be mild, more serious and life threatening injuries can also occur. The impetus for writing a dissertation on sports neurological injuries has come 
largely from clinicalpractice. In clinical practice and working with athletes it became clear that there was a gap between the overlapping tertitories, neuropsychology and neurology. Clearly, as with any borderland zone, there is a risk of relative neglect as each separate discipline has proceeded on its specialised way, leaving an uneasy interface between. Neurology deals directly with the apparatus of mind. Neuropsychology on its part deals essentially with mental functioning and has less to do with the hardware upon which cognition depends. One aspect of this uneasy interface is the belief of some that 'what you can't see don't exist', denying the complexity of human behaviour and the factors which can shape and distort it. Apart from the denial of complexity of behaviour there is a simple question "why anyone should be interested in cognitive impaiment in athletes". One answer is denial of complexity, the other is that until quite recently many people were not interested. For example, in psychology many professionals see cognition as a nonissue. For them. behaviour is simply a function of habits, or response probabilities. Other psychologists translate perception, organisation and memory e.g, in behaviour ignoring the problems of cognitive impairment. 'This dissertation tries to provide information to narrow the gap between newrology and neuropsychology and that it gives a comprehensive view of the cognitive, behavioural and emotional consequences of cerebral injuries. "This dissertation is based on the belief that determinants of complex human behaviour (coordination and control of thoughts) are fundamentally important. The other goal of this dissertation is to present studies and theoretical knowledge to assist medical and paramedical personel in diagnosing and recognizing symptoms of traumatic brain injury due to athletic activity.

The past decade has seen a growing interest in sportsneuropsychology. The interest is founded by ideas regarding the importance of cognitive processes and by the way brain injuries affects learning, memory, language, perception and attention. In addition to the more traditional role of neurology other approaches will be required to assess brain functioning, for instance neuropsychological assessment. Furthermore, there is some overlap between cognitive function loss and pathogenic mechanisms seen in brain injured athletes due to recurrent traumatic brain injuries (dementia pugilistica) and Alzheimers patients. From the convergence of neurology, neuropsychology and sports, we are gaining a new persepective on behaviour and cognitive functioning.

Since the beginning of the 1990's several sportsneuropsychological programs have emerged, mostly in Europe and the USA. One of the main sources of fosterments for sportsneuropsychological programs is the growing medical and political concern regarding TBI incurred in sports. This served in the USA as a stimulus for the 
Ametican Academy of Neurology to establish in 1997 guidelines for diagnosis and evaluation of the brain injured athlete. In the Netherlands, England, Norway, Iceland and Sweden there were governmental debates concerning the aftermath of professional boxing, professional soccer and questions were asked concerning medical guidelines to stop the detrimental neurologic-and cognitive effects of the sports mentioned above. The results: professional boxing is banned in Norway, Sweden and Iceland and money is invested in scientific programs with the aim to stop neurological injurics and cognitive impairment caused by sporting activities. In addition, recently two articles have been published in which a neurologist and neuropsychologist working with athletes provided information about treatment of brain-injured athletes ( $1-2)$. In these articles the authors showed their concern abour treament and follow-ups of athletes who sustained TBII and who are at risk for severe brain injuries. The articles highlighted three main issues that should be addressed by any guidelines for the management of TBI in sport: (a) appropriate management of TBI in sport at the time of the injury, (b) prevention of a catastrophic outcome telated to acute brain swelling, and (c) avoidance of cumulative brain injury caused by repeated concussions and the accumulations of trivial traumas.

Moreover, coaches and trainers may not be aware of the impact of TBI on cognicion and emotional behaviour. Frequently an athlete's physical recovery from a TBI creates expectations for adequate functioning. However, a normal physical appearance can severely mask underlying cognitive deficits associated with TBI.

In this study the term head injury refers to any traumatic injury to the head and face. The brain may be, but is not necessarily, injured. Damage may be restricted to soft tissue, vasculature, and peripheral nerves. Head injury should not be used interchangenbly with TBI because head injury, by definition, does not imply damage to the brain. TBI is a consequence of head injury in which damage to the head results in damage to the brain. Damage may result in symptoms that are transient or permanent. Long term impairment may be absent, trivial or severe (3).

Furthermore, focal and generalized brain traumas will be discussed. A focal injury is one that often results from a direct blow or penetration of the brain and tearing of cerebral substance or vessels. This results in a localized area of bleeding or lesion of a localized brain area against bony irregularities of the inner surface of the skull. In diffuse brain injury, in contrast to focal brain injury, there bas been a global effect on cerebral functioning and/or structure, usually resulting in a widespread dysfunction (4). 


\section{Epidemiology of traumatic brain injury (TBI)}

Today, traumatic brain injury (TBD) is one of the leading causes of disability and death among individuals under 45 years in the industrialised nations (5-6). TBI account for half of the deaths and most cases of permanent disabillity after injury (7). Epidemiological studies suggests that between 250 and 300 hospitall admissions a year $/ 100.000$ of the population in Britain involve a head injury (8). A rate that is at last three times greater than that of schizophrenia and a prevalence that is greater than the prevalence of for panic disorder (13). Furthermore, disorders arising from traumatic brain injuries are more common than any other neurological disease, with the exception of headaches (14).

Other epidemiological studies vary between $152-430 / 100.000$ of annual hospital admitted TBI $(9,11)$.

Of all hospitals admissions in Britain $7 \%$ sustained severe 'TBI, 18\% incurred moderate TBI and 75\% sustained mild TBI (8). In addition, Rutherford (1979) (10) showed that $50 \%$ with mild brain injuries (MTBI) experienced a range of post concussion symptoms including headache, dizziness, irritability, reduced concentration, memory dysfunction and emotional changes like anxiety and depression. These symptoms resolved usually within 3-6 months after injury. But it was calculated that $15 \%$ of the total MTBI population still experienced complaints one year after injury.

\section{Sports neuroepidemiology}

The exact incidence of traumatic brain injury related to sports can only be roughly estimated. World wide estimates of the incidence of TBI of all causes range from 152 to 430 cases per 100.000 population per year, which is consistent with the results of the British study (8). The percentage of brain injuries related to sports ranges from $3 \%$ to $25 \%$. Based on these figures, the rates of sportswrelated brain injuries could theoretically range from 5 to 68 cases with a median value of 42 per 100.000 person years (11). Other studies show that of all traumatic brain injuries, $10 \%$ to $22 \%$ are treated in hospitals and it is estimated that $11 \%$ of all hospital treated TBI in childten and adolescents are sports related (15-17). These numbers are in accordance with the estimation made by Kraus (11). Studies designed to identify all individuals who seek medical attention after TBI report that only $16 \%$ to $20 \%$ are admitted suggesting significantly higher incidence rates than those cited above (18-19). 
Since 1975, the National Athletic Injury/Illness Reporting System (NARS) has been following all athletic injuries in various sports, including concussion the most common head injury in sports. In the NAIRS system, a reportable concussion is any incident of disorientation caused by trauma that requires cessation of play to examine the athlete. The NAIRS report estimated the number of 250.000 concussions incurred in contact sports per year. With a population in the USA of 265 million people this means a number of 96 concussions in 100.000 person years, which is considerable higher than Kraus his figures. The average annual incidence of reportable concussion in selected college sports 1975-1978 showed (NAIRS report):

Table 1

\begin{tabular}{lcc}
\hline & Cases per 10.000 athlete exposures* & cases per 100 athletes * \\
\hline Amercian football & 11.1 & 2.2 \\
lce hockey & 3.5 & 3.7 \\
Westling & 3.0 & 2.5 \\
Soccer & 2.7 & 1.6 \\
\hline
\end{tabular}

* exposure is matches and training;

*at an whole sports career

Severe TBI is incurted in boxing (20) and sports with a high velocity like skiing. In professional boxing $20 \%$ of the boxers is developing boxing dementia, $45 \%$ show brain abnormalities seen on CT- and MRI scans and $90 \%$ develop severe to moderate chronic neuropsychological impaiments (21-22). Even soccer players are vulnerable for traumatic brain injury. In the Netherlands $54 \%$ of the professional soccer players incur one or more concussions during their career (23). American studies show a concussion rate of $59 \%$ in male amateur players in two soccer season's (24). In professionals $45 \%$ of the soccer players show chronic neuropsychological impairments (23). Even in adolescents specific chronic neuropsychological problems are documented caused by playing soccer (25). In retired amateur soccer players $33 \%$ of the players show CT-scan abnormalities, and $81 \%$ show chronic neuropsychological impairments (26-28).

'The incidence of injury to peripheral nerve in sports is largely unknown. Periphexall nerve injuries incurred in sports are relatively uncommon and are not typically detected by injury surweillance systems (29). 


\section{Causes of TBI in sports}

\section{Initial mechanical damaging factors}

A change in the velocity of the brain caused by a blow to the cranim can produce linear and rotational mowements of the brain within the skull (30). When the sicull and the brain within it are accelerated coup-contrecoup injuries can occur. The bruise spots at the impact side are called coup lesions; contrecoup lesions are located in the area opposite the blow (31).

After a rapid rotation of the head (for example, when an athlete is hit by a blow coming in at angle) diffuse axonal injury (DAI) and stretching and snapping of blood vessels may occur. The rotation of the brain within the cranial vault tends to be delayed relative to the initating change in velocity, because of the biam's intrinsic inertia. This lagging movement of the brain leads to stretching and shearing forces on the fibers (DAI) and blood vessels (subdural and intracerebral hematomas) (32 34). Common locations of DAI after closed head trauma include: cerebral hemispheric gray-white matter interface, subcortical white matter, body and splenium of corpus callosum, basal ganglia, dorsolateral aspect of brainstem and cerebellum (35). Subdural hematomas (acute, subacute, and chronic) and intracerebral hematomas have effects that are specific to their locations, extend and degree of neuronal damage. The brain can also be injured when the moving head suddenly stops as in falls or collisions with other players. The moving head and the brain within it are stopped, followed by a sudden deceleration until the brain's movement stabilizes. Coup-contrecoup injuries and shearing injuries can result. $A$ s an example, falls on the back of the head may result in fracture of the skull and contrecoup contusions on the orbital surface of the frontal lobes and the tips of the temporal Jobes. In falls and sudden stops of the moving head, the acceleratingdecelerang brain slides around whin the cranial cavity over bony structures who surround the orbital and frontal areas along the base of the skull (36). This is why most traumatic brain injurjes ate located in this region. Pudenz \& Shelden (37) observed in 1946 the brains of monkeys after replacing theit skull caps with transparant material during and directly after a head strike. Switling movements of brain tissue could be witnessed after acceletation injury, both at the point of impact and elswhere.

In general, TBI is often a result of an interaction between linear and rotational forces and is seldom due to pure rotational or linear acceleration (20). 
Brain damage can also be induced by hypoxia. Stranguhation techniques in martial arts, for example, in which the blood supply to the brain is blocked by pressure on the carotd atteries, can produce hypoxia and unconsciousness if the victim fatls to submit and subclinical clectroencephalographic abnormalities may be induced ( 38 39). During hypoxia, free radicals and excitotoxic neurotransmitters, such as glutamate, are released and result in furthet damage to newrons (40-41).

\section{Secondary brain damage}

TBI occurs in different ways, involves different mechanisms, and results in different types of clinical disorders. The velocity, localization, and direction of mechanical force at impact as mentioned before are not the only specific factors that contribute to TBI. Cerebral injury can also start afrer the primary injury and results of a series of biochemical steps that are set in motion by the primary injury (4). It can be concluded that TBI should be seen as a process and not as an event (32).

\section{Physiological changes after mechanical impact to the head}

The early experimental srudies by Dennie-Brown \& Russel in the 1940's (42) showed a number of transient pathophysiological changes immediately after a concussive blow to the head. They observed depression of cardiac-, vasomotor- and respiratory functions as well as paralysis of brain stem reflexes. Remarkable is the fact that loss of brain stem reflexes could only be produced if the head was free to move when struck (42). This may explain why, for example, concussion is common when the head is in motion at the time of injury, but relatively rare in static crushing injuries. Further studies in animal models have confirmed these observations (43 44).

\section{Biochemical changes after mechanical impact to the head}

There have been several studies of neurochemical changes after TBI. Secondary neurologic injuries are partly due to ischatemic-hypoxic injury. "The secondary injury. and cell death are mediated by progressive increases in intracellular CA2t. concentration due to activation of $\mathrm{Ca} 2+$ permeable gilamate teceptor (i.e., Nmethyl-D-aspartate (NMDA) receptors and, to a lesser extent, activation of voltagegated CA2+ channels. Pathological increases in $\mathrm{K}+$ concentration facilitate intracellular Ca $2+$ accumulation by causing massive membrane depolarization. Elevated K concentrations depolarizes synaptic terminals, facilitating the release of glutamate. Moreover, the accivation of postsymaptic NMDA glutamate receptors 
also requires membrane depolatization. Finally the membrane depolarization associated with these uncontrolled increases in $\mathrm{K}+$ concentrations activates damaging $\mathrm{CA} 2+$ entry by opening voltage-gated $\mathrm{Ca} 2+$ channels (4).

From other studies it is evident that TBI can affect the neurotransmitter systems that mediate mood and affect, including norepinephrine, serotonin, dopamine and acetylcholine (45-46). Other studies show enhanced concentrates in serum and cerebrospinal fluid of proteins synthesised in astroglial cell or neurons as markers of cell damage in the central nervous system. Increased levels of these proteins in cerebrospinal fluid (CSF) and serum have been observed in TBI victims (47-48). Philips et al (49) found in 1980 raised serum concentrations of of creatine kinase isoenzyme $\mathrm{BB}$ (CK-BB) in 14 of 22 patients with concussions. Nordby et al (50-51) reported increased serum and CSF levels of $\mathrm{CK}-\mathrm{BB}$ in $23 \%$ of their concussed patients. Raise in serum levels of S-100 could possibly predicts outcome after injury (51).

The studies mentioned above demonstrate that the sequelac of TBI depend not only on the primary mechanical damage but also on the complex of interaction of pathophysiologic and biochemical events that follow the initial distortion of brain tissue.

\section{Classification of head injury}

\section{The Glasgow Coma Scale}

The Glasgow Coma Scale (GCS) is desigmed for assessing the level of consciousness by establishing a rating concerning three aspects of behavior: motor responsiveness, verbal performance and eye opening (53).

\section{Table 2 Glasgow Coma Scale}

\begin{tabular}{|c|c|c|}
\hline \multicolumn{3}{|l|}{ Eye Opening Response } \\
\hline Spontaneously & 4 & Reticular activating system is intact; paticnt may not bet atwate \\
\hline To werbal command & 3 & Opens eyges when rold to dosso \\
\hline ToPan & 2 & Opens eyes in response to pain \\
\hline None & 1 & Does mot open eyes to any snimuli \\
\hline \multicolumn{3}{|l|}{ Verbal Response } \\
\hline Oriented-converses & 5 & $\begin{array}{l}\text { Relatively intaci CNS } \\
\text { Aware of self and cowiromment }\end{array}$ \\
\hline Disoriented-converses & 4 & Well ariculatcd, organized, but patient is disoriented \\
\hline Irappropriate Words & 3 & Random, exclamatory words \\
\hline Inoomprehensible & 2 & Mowning, no recognizable words \\
\hline Noresponse & 1 & No response or intubated \\
\hline
\end{tabular}




\section{Miotor response}

Obeys werbal commands

Localizes to painfull stinnti

Flewicn withdrawal

Abnormal fexion

6 Readily moxes limb when told to

5 Moves limb in an ef fort to renowe painfull stimuli

4 Pulls away from pain in flexion

Extension

3 Decorticate rigidity

2 Decebrate rigidisy

$\frac{\text { Wormal }}{\text { CCS scare }=\mathrm{E}+\mathrm{M}+\mathrm{V}}-\frac{15}{\text { None }}$

The patient's clinical state is charted regularly on the functions mentioned above. Numerical scores are summated for the best responses obtained under each category at a defined point in time. By observing and classifying these responses, one can quantify the level of consciousness. The scores have a range from 3 (totally irresponsive) to 15 (fully awake and alert). In this way useful predictions can be made, often within 24 hours of injury and more

certainly writhin the first week. The GCS has reached general acceptance as a reliable measure of the level of consciousness for clinical and research purposes and is now in routine use in many countries, in units caring for acute head injured patients.

Stein \& Spettel (54) presented in 1995 (Table 3) the Head Injury Severity Scale (HISS) based on GCS scores. The HISS is designed to seperate minimal injuries with negligable risk of complications from mild and severe injuries requiring medical attention.

Table 3 The Head Injury Severity Scale (HISS)

\begin{tabular}{|c|c|}
\hline HUIS category & Clinical characteristic \\
\hline \multirow[t]{2}{*}{ Minimal } & $\operatorname{GCS} 15$ \\
\hline & No loss of consciousness or amnesia \\
\hline \multirow[t]{2}{*}{ Mile } & $\operatorname{GCS} 14$ or 15 \\
\hline & $\begin{array}{l}\text { Brief (c } 15 \text { minutes) loss of consciousness or annesia or impaired } \\
\text { alerners or memory }\end{array}$ \\
\hline \multirow[t]{2}{*}{ Moderate } & $\operatorname{GCS} 9-13$ \\
\hline & or $L O C>5$ minutes, or focal neutological deficit \\
\hline
\end{tabular}

\section{Amnesia in relation to severity of traumatic brain injury}

On recovery of consciousness, events often fail to be recorded in memory for a period of time. Often patients report a post-txaumatic amnestic gap after head injury. The importance of the duration of amnesia as a guide to the severity of injury and 
prognosis for recovery was already shown in the 1930's (55). Post traumatic amnesia (PTA) has now become a widely used part of clinical practice to predict sewerity of injury. The lenghts of PTA may be defined as the time from the moment of injury to the rime of resumption of normal continuous memory and can be used as a guide to quantify the degree of severity (Table 4).

Table 4 PTA (classification according to Bigler, 1990) (56)

\begin{tabular}{lll}
\hline PlA duration & Severioy \\
\hline$<5$ & minutes & Very midd \\
$5-60$ & minutes & Mild \\
$1-24$ & hours & Moderate \\
$1-7$ & days & Severe \\
$1-4$ & weelss & Very severe \\
More than 4 weeks & Extremely severe \\
\hline
\end{tabular}

\section{Concussions}

Concussions are often uncurred in sports. In boxing and martial arts, concussions are common and inevitable because victory is direct by rendering the opponent unconscious by a grade three concussion (according to the AAN classification, 1997) (56). In collision sports like soccer a high frequency of concussions due to collisions between players are documented (23). Even in non-collision sports like horse back riding, biking, sking, ice skating, roller skating, skateboarding, and in-line skating, concussions are often reported as a result of collisions and falls (58-62).

Kelly and Rosenberg (1) define concussion as a trauma-induced alteration in mental status that may or may not involve loss of consciousness. Some frequently observed features of concussion are vacant stare, inability to focus attention, disotientation (walking in the wrong direction, being unaware of time, data, place), slurred or incoherent speech, incoordination, emotional lability, memory deficits, problems with abstract reasoning, slowed feaction time, slowed mental- and motor speed, problems with planning and judgment, and diffuculties in processing novel or complex visual spatial stimuli $(63-68)$.

Symptoms of concussion can be classified as early and late. Latly symploms (minutes to hours after injury) are headache, dizziness or vertigo, lack of awareness of surroundings, nausea, and vomiting. Late symptoms (days to weeks after injury) are persistent low-grade headache, light headedness, poor attention and concentration, 
memory dysfunction, inefficient information processing, inadequate perceptual processing, problems with planning; and slowed reaction time, intolerance of bright lights or difficulny focusing vision, intolerance of loud noises, sometimes tinging in the ear, easy fatiguability, irritability and low frustration tolerance, anxiety, depressed mood, sleep disturbances (1).

Athough, many concussions seems mild at the time of injury, the range of symptoms can be wide and long lasting.

Concussions are graded in three categries: according to AN norms (1997) (grading according to the Quality Standards Subcomwittec: Practice Parameter) (57).

Grade 1 Concussion: Transient confusion, no loss of consciousness, and a duration of mental status abnormalities of $<15$ minutes

Grade 2 Concussion: Transient confusion, noloss of consciousness, and a duration of mental status abnormalities of $>15$ minutes

Grade 3 Concussion: Loss of consciousness (LOC), either brief (seconds) or prolonged (minutes or longer).

\section{Cumulative effects of concussion}

Cumularive effects of concussions such as, disabling headache, classic migraine, and delayed recovery of brain functioning (after a second concussion) have been reported in studies of concussion victims $(67,69)$. Repeated mild brain injuries occuring over an extended period (i.e., months or years) can result in cumulative neurologic- and cognitive deficits. Gronwall and Wrightson (70) found that deficits in information storage and retrieval were exacerbated by successive injuries occurring over an extended period (i.c., months or years). Repeated mild brain injuries occurting within a short period (i.e., hours, days, weeks) when someone is still symptomatic from the former insult can be catastrophic or fatal ( $11-72)$.

\section{Postconcussion syndrome}

The postconcussion syndrome is often reported in athletes, especially those with repeated or successive concussions during the course of one season (4). Carlsson and co-workers (73) found a strong correlation between the degree and the extend of post-concussive symptoms and the number of previous head injuries, and conjectured that the cumulative effects of repeated head injury play a significant role in this syndrome. 
The postconcussion syndrome consists predominantly of deficits in cognition, the sense of physical well being, and mood (Table 5). A mulritude of complaints can occur with post concussion syndrome including persistent headache, irritability: concentration problems, memory problems, vertigo and generalized fatigue. Often these symptoms occur in the absence of any neurological abnormalities on examination. Most symptoms are typically short-lived and tesolve spontaneously; however, in a small number of athletes, problems may become persistent (74). "The aetiology of the post concussion syndrome has long been debated. Psychological factors are frequently evoked to explain such symptoms in an otherwise 'normal' individual. As an example, Cook (75) studied at the end of the sixties 300 amateur rugby players suffering at least 1 concussion. Over $60 \%$ of the rugby amateurs reported headaches after injury but in three-quarters the headaches resolved within 48 hours. Only $17 \%$ were unable to work, with $80 \%$ returning in less than 1 week. Cook attributed the rapid recovery in athletes to a high motivation. However, Barth et al (76) demonstrated neuronal loss and and microscopic lesions in the brainstem in post concussion syndrome patients. In addition, as many as $50 \%$ of patients with post-concussion syndrome have abnormalities on brainstem evoked potential studies (77). Moreover, MRI has shown a variety of abnormalities in the frontal and temporal regions in post concussion syndrome patients with normal CT-scans (78), Such information, taken in combination, would indicate that at least in some athletes with post-concussion syndrome symptoms underlying neuropathological or structural abnormalities in the brain are induced by (repeated) mild brain injuries.

Table 5 Postconcussion syndrome

\begin{tabular}{lll}
\hline Cognitive & Personality & Somalic \\
\hline Memory & Depression & Headaches \\
Attention & Mood changes & Dizziness \\
problem solving & Motivation & Photopholian \\
Word finding & Anxiety & Difficulty sleeping \\
Fluency & Irritability & \\
Tiredness (psychic and somatic & & \\
\hline
\end{tabular}

\section{Dementia pugilistica}

Athletes can develop a severe chronic progressive traumatic encephalopathy after being exposed to a cumulation of (mild) traumatic brain injuries. The syndrome follows in three-stage clinical pattern. 'The first stage is manifested by affective disturbances and mild motor incoordination. In the second stage, affective symptoms increase; paranoid ideas and mild dysarthria and tremor may appear. 
The third stage is characterised by a decrease in general cognitwe functions (memory deficits, dysarthria, motor incoordination), impaired hearing, hyperreflexia, and intention ttemor. Furthermore, dementia, personality change (immaturity, aggressiveness, suspiciousness), and social instability have been described. (79-81).

\section{Diffuse brain swelling/second impact syndrome (SIS)}

It has been well documented that a fatal outcome may result from repeated minor head injuries occurring in short succession (1). Saunders and Harbaugh (82) reported in 1984 a case of a 19 year old college football player who was involved in a fist fight and received a blow to the head resulting in a brief loss of consciousness. Four days later he was involved in in a football game and, despite receiving no unusual head impact he collapsed on the field. He died 4 days later with diffuse and uncontrollable cerebral edema.

Diffuse cerebral swelling is a rare but well recognized cause of delayed catastrophic deterioration resulting in death or persistent vegetative state after an apparendy minor head injury. Risk factors for this post traumatic complication have not been established, although most cases occurred in children and adolescents $(71,83)$. This phenomenon has also been observed in collision sports (84).

It has been postulated that a specific form of cerebral swelling may be the consequence of a repeated minor head injury. 'The 'second impact syndrome' (SIS) results from acute, usually fatal, brain swelling that occurs when a second head blow is sustained before complete recovery from a previous concussion. Brain swelling apparently resuits from a failure of autoregulation of cerebral circulation causing vasoparalysis which in turn causes increased intracranial pressure, which may be difficult or impossible to control. This complication can result in brainstem herniation and death $(72,85)$. The second impact syndrome has been reported more frequently since it was characterized in $1984(72,82)$. Combined data from four states in the USA (Colorado, Missouri, Oklahoma and Utah) indicates an annual rate of 2.6 cases per 100.000 population of sports related TBI resulting in hospitalization or death. A though rare, sports related diffuse cerebral swelling has a high mortality. If SIS represents a real clinicopathologic entity, then there are potential major consequences for the management of minor head injuries in sports and implications for the innumerable amateur- and professional athletes who sustain such injuries. Since all previously reported cases of second impact syndrome victims show the common feature of an athlete who remains symptomatic (e.g., headaches, dizziness) after the first injury, a number of guidelines have been established for allowing a return to competition after a concussion. Many of the published case reports $(82,86)$ 
and most notably the guidelines of the Colorado Medical Society and the American Academy of Neurology suggest that prevention of this syndrome should be based on a policy of not allowing individuals to renum to sports until postconcussive symptoms have fully resolved $(57,85,87)$.

\section{Why is the brain so vulnerable for second injuries?}

\section{Metabolic disturbances}

Essential for understanding the vulnerability of the brain for second injuries is the fact that the minutes to few days following concussive injury, cells which are not irreversibly destroyed, remain alive but exist in a vulnerable state. Experimental animal studies have identified metabolic dysfunction as a major post-concussive physiological event which produces and maintains this state of vulnerability. This period of enhanced vulnerability is characterized by both an increase in the demand for glucose and an inexplicable reduction in cerebral blood flow. The result is an inability of the neurovascular system to tespond to increasing demand for energy in order to te-establish its normal chemical and ionic environments. In animal studies, the concept of injury-induced vulnerability have indicated that up to three days following a concussion, a reduction in cerebral blood flow, which would be normally well-tolerated, now produces extensive neuronal cell loss (88-92). Moreover, some studies using animals conclude that the mismatch between glucose demand and fuel availability can even be seen following mild concussive brain injury (93-94).

Whatever the mechanism, it seems to be clear that a concussion can produce a state of vulnerability for surviving nerve cells. This state can be characterized in terms of a metabolic dysfanction which can last for days. When the brain is sustaining another concussion in this critical period, massive neutonal cell loss can be the result.

\section{References}

Chapter 1

1. Kelly JP. Rosenberg.JH. Dirgnosis ard management of concussion in sports. Numollogy Toy?; $48: 575-580$

2. McCrea M. Use of standardized assesstnent of concusion (SAC) in the inmediate sideline examination of tootball plagers. Newrology 1907: 48:586-588.

3. Kay $T$, Newman B, Cavallo M, Eztachi O, Resnick M. Townd a newopsychological model of

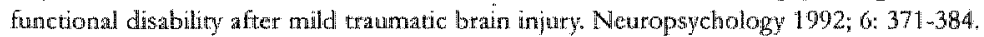

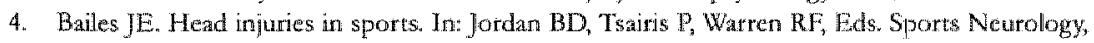
2nd edition. Pthiladelpha: Lippincott-Rawen, 1908. 
5. Coldstein M. Tramatic brain injuries; a silent epidemic. Anuals of Neurology 1990; $27: 327$.

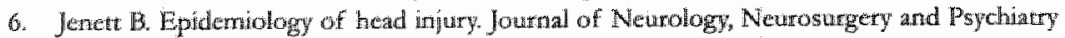
$1996 ; 60: 362-369$.

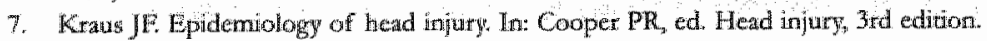
Baltimore: William Whildis, 1993.

8. Jennet $\mathbb{B}$, MacMillan R Epiderniology of head injury. British Medical Journal 1981; 282: $101-104$.

9. Klauber MR, Barret-Connor E, Marshall LR, Bowers SA. The epidemology of head iniury: a prospective study of an entire community - San Diego County, California, 1978. Americar Journal of Epidemiology 1981; 113: 500-50\%.

10. Rutherford WH, Merrett $J D_{0}$ McDonald JW. Symptoms at one year following concussion from minor head injuries. Injury 1979; 10: 225-230

11. Kraus JF, Epidemiologic features of injuries to the central nervous sgstem. In: Anderson DW, ed. Awroepidemiology, a tribute to Brace Schoenberg. Boca Raton, FL: CRC Press 1991; 333-357.

12. National Anhletic Injury Reporting System. Pennsyluania State University, 1979.

13. Silver JM, Hales RE, Yudofiky SC. Psychiatric consultation to neurology. In: Tasman A, Goldfinger SM, Kaumann CA, Eds. Ametican Pisychiatric Press Review of Psychiary, wol 9. Washington DC: American Psychiatric Press, 1990; 433-465.

14. Kurzke JF: Neuropidemiology. Ann Newrol 1984; 16: 265-277.

15. Lehman LB. Nerwous system spors-relared injuries. American Journal of Sports Medicine 1987; $15: 494 \% 99$,

16. Frenquelí A, Ruscito 1 , Sicciolo $G$, Rizzo $S$, Massarcli N. Head and neck trauma in sporting activities:Review of 208 cases. Journal of Cranionax. Surgery 1991; 19: 178-181.

17. Hansen $7 \mathrm{~B}$, Pless $\mathrm{S}$, Brawers $M$. Cranial injuries among children in the county of Ringkobing. Ugeskr Laeger 1991; 15:2947-2479.

18. Strang $I$, MacMilian, $R$, Jennett $B$. Head injuties in accident and emergency departments $a t$ Scotrisch hospitais. Injury 1978; 10: $154-159$.

19. Fife D. Head injury with and without hospital admission: companison of incidence and shorttume disability, American Journal of Public Heal th 1987, 77: 810-812.

20. Jorkin BD. Neurologic aspects of baxing Archives of Neurology 1987; 44:453-459.

21. Casson RI, Sham R, Campibell Eam et al. Neurological and CT evaluation of knocked out boxers. Journal of Neutology, Neurosutgery and Psychiary 1982; 45: 170-174.

22. Casson IR, Seigel O, Sham R, Camplell FA, Tarlau M, Didonenico A. Bain damage in modern boxers. JAMA 1984:251:2663-2667.

23. Matser JT, Kessels AGH, Jordan BD, Lezak MD, Troost J. Chronic iraumaric brain injury in active professional socer players. Neurology 1998; $51: 791-796$.

24. Boden BP, Kirkendsll GT, Garret WE jr. Concussion incidence in elite college soccer players. American Journal of Spotts medicine $1998 ; 26: 238241$

25. Witol $A$ Webbe 1 . Netropsychologichl deficits associated with soccer phay. Archives of Chinteal Neuropsychology 1994; $9: 104-105$.

26. Tysvaer AT, Storli O, Bachen NI. Soccer injuries to the bran. A neurologic and electroencephalogtaphic study of former players Acta Neurologica Scandinavica 1989; 80: 151156.

27. Tyswaer $A T$, Lochen $\mathbb{E A}$. Soccer injunies to the brain. A neurtopsychological study of former soccer players. The American Joumal of Sports Medicine 199:; 19:56-60. 
28. Sordand $O$, Tysvaer AT. Brain damage in former association football players. An evaluaton by cerebral computed tonography. Neuroradology $1989 ; 31: 44,48$.

29. Clarke KS, Jordan BD. Sports Newroepidemiology In: BD Jordan, P Tsaris, RF Warnen, Edis. Sports Neurology, 2nd edition. Philiadelphia: Lippincott-kaven, 1998; 3-13.

30. Holbourn AHC Mechanics of head injuries. Lavee $1943 ; 2 ; 438$-441.

31. Zomeren vat $A H$, Burg van den W. Residual complaints of patienrs two years after sevene herd iniury Journal of Neurology; Neurosurgery and Psychitaty 1985; 48: $21-28$.

32. Gennarelli TA. The pathobiology of tramatic brain infury. Neuroscientist $1997,3: 73-80$.

33. Strich Sy. Shearing of netwe fibers as a cause of brain damage due to head injurge A pachological study of twenty cases. Iance $1961 ; 2: 443-448$.

34. Lampert PW, Hardman JM. Morphological changes in brains of boxers. JAMA 1984 251: 26762679 .

35. Oxsalak PM, Goethem van JW, Hauwe wan den L, Dillen C, Verlooy J, Cosyns P, Scheppet dle AM. Imaging findings in diffuse axomal injury after closed head numa. Buropean Radiology $1998 ; 8: 960-965$.

36. Courville; CB. Pathology of the Nerwous Sysem, 2nd edition. Mountain View CA: Pacific Press, 1945.

37. Pudenz RH \& Shelden CH. The lucite calwaturn-a method for direcr observation of the brain. Joumal of Meurosutgery $1946 ; 3 ; 487-505$.

38. Owens RG, Ghadiali IJ Judo as a possible cause of anoxic brain damage Joumal of Sports Medicine and Physical Fitness 1991; 31: 627-628.

39. Rau R, Raschak $C_{n}$ Brunner $K$, Banaer W Spectral analysis of ectroencephalography changes after choking in judo (juji-jime). Medicine \& Science in Spores \& Exercise 1998; 30: 1356-1362.

40. Becker DP, Verity MLA, Povlishock J, et al. Brain cellulat injury and recoverye horizons for improwing medical therapies in stroke and tranuma. West J Med 1988; 148:670-684.

41. Faden A., Demediuk P, Panter $S$, et al. The role of exitatory amino acids and NMDA receptors in traumatic brain injury. Science 1989; 244: 798 - 800 .

42. Demag-Brown D, Russell WR. Experimental cerebral concussion. Bran 1941; 64: 93-164.

43. Eison LM, Ward C. Mechanisms and pathofysiology of mild head in ury. Semin Newrol 1994: 14: 8 . 18.

44. Gennareli TA, Thibanilt IIE, Adams Jh. Diffuse axonal injury and traumatic coma in the primate. Ann Neurol 1982; 12:564-574.

45. Clafon GL, Ziegler $\mathrm{MG}_{\mathrm{g}}$ Grossman, RG, Circulating catecholamines and sympathetic activity after head infury. Neurosurgery 1981: 8: 10-14.

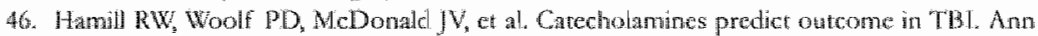
Nourol 1987: 21:438-443.

47. Veche C, wan Woekom TCAM, Teeken AW, et al Homovanilic acid and 5uhydroxyindotencetic acid cerebrospinal flud levels. Archives of Neurology 1975; 32:792797.

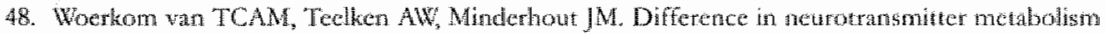
in fronto-temporallobe contusion and difuse cerebral contusion. Lancet $1977 ; 1: 812812$.

49. Philips JP, Jones HM, Hitchcock R. Radioimmunoassay of serum creatine kinase BB as index of bran damage afee head injury. British Medicall loumal 1980; 281; 777.779.

50. Nordby HK, Urdal P. The diagnostic walue of measuring creatinc kinase BB acrivity in cerebrospinal fuid following acute head injury Acta Netrochirumgica 1982; 65:93-101.

51. Nordby $H K$, Urdal $P_{\text {. B }}$ Bornaes $\mathbb{H}$. The prognosis of patents with concussion and increased crearine kinase BB in cercbrospinal nuid. Acta Neurochirurgica 1984; 71; 205-215. 
52. Woergen $\mathrm{C}$, Rothoer RD, Holzschuh Comparison of scrial $\$-100$ and NSE mezsurenents after

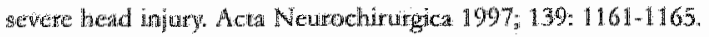

53. Teasdale $G$ Jennet $B$. Assessment of coma and impaired consiciousness $A$ practical scale. Juncet $1974: 2: 81.84$.

54. $\operatorname{sich} 5 \mathrm{C}_{\mu}$ spetuel $\mathrm{C}$. The head injury severity scale (HIS5): a practical classification of dosed head ingury. Brain Injury 1995; $9: 437444$.

55. Ruscel Werebral involwement in thend infury Brain 1932; 55: 349.603 .

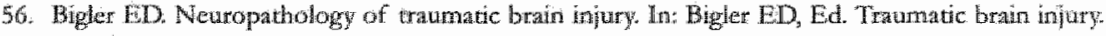
Ausin, Texas, 1990

57. Ametican Academy of Neurdogy. Tyactice parameter: the management of concussion in sports (stumaty statement). Neutology 1997; $48: 581-585$.

58. Hamilton $M G$, Trammer BI. Nervous system injuries hors ho back riding accidents fournal of Trauma 1993; 34: 227.232.

59. Frank $\mathrm{B}$, Frankel P, Mullins RI, Taylor $\mathrm{N}$. Injuries resulting from bicycle collisions. Acad Emerg Med $1995 ; 2 ; 200-203$

60. Mellion MB. Common cycling injuries. Management and prevention. Sports medicine 1991: 11: $52-70$.

61. Calle SC, Eaton RG. Whets-in line skatrig injuries Joutnal of Trama $1993 ; 35: 946-951$.

62. Schieber RS, Branche-Dorsey CM, Ryann GW Comparison of in-Line skating ininuries with wollerskating and skateboatd injuries. JAMA 1994; 271 : 1856-1858.

63. Dencker SV A follow up study of 128 closed head injurites in turins using cow wins as controls. Acta Psychiat Neurol Scan 1958, 33:123-125.

64. Jacobsen I, Baddsgafurd SE, Thornsen S, hemritken PB. Prediction of post concussional sequelae by reaction time test. Acta Neurologica Scandiravia 1987; 75:341-345.

65. Rimel RW, Giordan B, Barth JT, Boll TJ, jane JA. Disability caused by minor head jajury. Nentosurgery 1.981;9:221-228.

66. Kein M. Cognitive aging, attention and mild traumatic bratn inịury. Thesis, Department of Neuropsychology University Maastrichth, 1997.

67. Rutherford WH, Meret JD, Mc Donald JR. Symptoms at one yenr following concussions from head injurtes. Injury 1979; 10:225-230.

68. Miller JD. Head injury. Journall of Neurology, Neurosurgery and Psychiatry 1993; 56:440-447.

69. Wrightson $\mathbb{P}_{3}$ Gronwall D Time of wark and symptoms after minot head injury. Injury 1980; 12: $445-454$

70. Cronwall D, Wrightion P. Cumulative effect of concussion. Lanee 1975;2:995-997.

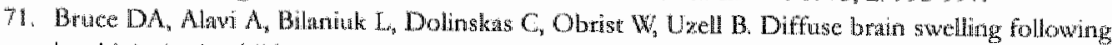
head injuries in childrent the syndrome of "malignant brain edena". Joumal of Neurosurgery $1981 ; 54: 170178$.

72. Cartu $\mathrm{RC}$, Voy $\mathbb{R}$. Second impace spondrome a risk in any contact sport. The Physician and Medicine 1995; 23: 27-34.

73. Carlsson $G S_{\mathrm{x}}$ Swatsodd $\mathrm{K}$, Welm L. Long term effects of head irjury sustaned during life in three male populations Journal of Neurosurgern 1987; 67: 197-205.

74. Whberger JE. Minar head injuries in American football: prevention of long term sequelae. Sports Medicine 1993; $15 ; 338-343$.

75. Caok JB. The effects of minor head injury" suscaned in sport and the post concussional syndrome lin Walker et al., eds. Delayed effects of head injury. Thomas, Springfield, 1969; 408 a 413 
76. Barth JT, Macciocchi SN, Giordani B. Neuropsychological sequelae of minor head injury* Neurosurgery $1983,13,529-533$.

77. Rowe MJ, Carlsson C. Brainstem auditory evoked potentials in post concussion dizziness. Archives of Neurology $1980 ; 37: 379-683$.

78. Levin $H S$, Amparo $\mathbb{E}$, Eisenberg HM. MRI and CT in relation ro neurobehavioral sequelae of mild and moderate head injury. Joumal of Neurosurgery 1987; 66:706-713

79. Robberts AH. Brain damage in boxers. London: PitmannMledical and Scientific, 1969.

80. Robberts GM, Allsop D, Bruton C]. The occult aftermath of boxing Joutnal of Neurologys Newrosurgery and Psychiatry 1990: 53:221 228.

81. Hollnagel P. Punch drunk syndrome. Ugeskr Laeg 1974; 136: $2871-2874$.

82. Saunders RL, Harbaugh RE. The second impact in catastrophic contact-sports head trauma. JAMA 1984; 252: 538-539.

83. Pickles W. Acute general ediema of the brain in children with hend injuries. New England Journal of Medicine $1950 ; 242 ; 607-611$.

84. McCrory P. Berkovic SF. Second impact syndrome. Neurology 1998; 50:677-684.

85. Kelly JP, Nichols JS, Filley CM, Lillehei KO, Rubinstein D, Keinschmidt-DeMaster BK. Concussion in spotts: guidelines for the prevention of catastrophic outcome. JAMA 1991; 266: $2867-2869$.

86. McQuillen JB, MeQuillen EN, Morrow P. Trama, sport and maligant cerebral edema. American Journal of Forensic Medical Pathology 1988; 9: 12-15.

87. Colorado Medical Society. Report of the sports medicine comintee guidelines for the management of concussion in sport (revised). Denver: Colorato Medical Society, 1991.

88. Jenkins LW, Moszynski $K$, Lyeth $B G_{\text {, }}$ et al, Increased vulnerability of the mildly tramatized rat brain to cerebral ischemia. The use of controlled secondary ischemia as a research tool to ddentify common or different mechanisms contributing to mechanical and ischemic brain injury. Brain res 1989; 477: 211-224.

89. Jenkins LW, Marmatou $A$, Lewelt W, Becker DP. Increased vulnetability of the traumatized brain to early ischemia. Baetmann A, Go GK. Unterberg (eds); $273.282,1996$.

90. Lee SM, Lifshitz J, Hovda DA et al, Focal cortical impact injury produces inmediate and persistent deficits in metabolic auto-reguilation (Abstract). J Ceteb Blood Flow Metab 1.995; 15: 722

91. Lifshitz J, Pinanong P Le HM, et al. Regional uncoupling of cerebral blood flow and metabolism in degenerating cortical areas following a lateral cortical contusion. joutnal of Neurotrauma 1995; 12: 129.

92. Sutron RL, Hovda, DA, Adelson PD, et al. Metabolic changers followning cortical contusion. Relationships to edema and morphological changes. Acti Neurochir 1994; 60; 446.448.

93. Hovda DA, Le HM, Lifshitz J, ct al. Long term changes in metabolic rates for glucose following mild, moderate and severe concussiwe head injuries in adult rass. Soe Neurosci 1994; 20: 84:5.

94. Katayama $X, B$ ecker $D P$, Tarnura $T$, et al Massive increases in extracellular potasisim and the indiscriminate release of glutamate following concussive brain injury. Journal of Neurosurgery $1990 ; 73: 889-900$. 
Chapter 2

\section{Acute traumatic brain injury in amateur boxing*}

JT Matser Msc (1), AGH Kessels MD (2), MD Lezak PhD (3), J 'Troost MD (4), BD Jordan MD (5).

1. Department of Anatomy, Faculty of Medicine and Health Sciences, Erasmus University Rotterdam

Department of Sportsneurology, St Anna Hospital, Geldrop, The Netherlands.

2. Research Unit Patient Care, University Hospital of Mastricht, The Netherlands.

3. Department of Neurology, Oregon Health Sciences University, Portland OR, USA.

4. Department of Neurology, University Hospital of Maastricht, 'The Netherlands.

5. Traumatic Brain Injury Program, Burke Rehabilitation Hospital, White Plains, New York, USA.

* Matser JT, Kessels AGH, Lezak MD, Jordan BD, Troost J. Acute traumatic brain injury in amateur boxing. The Physician and Sportsmedicine 2000; $28(1): 87-92$ 


\section{Abstract}

Objective: Acate traumatic brain injury (ATBI) represents the neurological. consequence of concussive and subconcussive blows to the head in millions of athletes annually. Evidence suggests that ATBI may be associated with boxing and. collision sports like American football and soccer. The objective of this study was to determine the presence and nature of cognitive impairment due to ATBI. Moteover, all boxers in this study used head gear during their fights and the second oblective was to determine if head gear could reduce the risk for ATBI in amateur bosing:

Design: In this inception cohort study thirty-eight amateur boxers were tested before and shortly after a boxing match and were compared to in control group of 28 amateur boxers who were tested before and after a comparable physical test. The participants in this study underwent neuropsychological examination. The main outcome measures were neuropsychological tests proven to be sensitive to cognitive changes incurred in contact and collision sports.

Results: The boxers who competed exhibited an ATBI pattern of impared performance in planning, attention, and memory capacity when compared to controls.

Conclusions: Participation in amateur boxing matches may adverscly affect neurocognitive functioning despite the use of headgear. "The neurocognitive impairment resembles cognitive symptoms due to concussions. Guidelines ate recommended to reduce the risk for cumulations of $\mathrm{A} T \mathrm{C} B \mathrm{~B}$, second impact syndrome (SIS) and difuse cerebral swelling (brain edema).

Keywords: acute traumatic brain injury, boxing, collision sports, cognitive impairment

\section{Introduction}

Moderate to high incidences of acute traumatic brain injury (ATBI) are reported in sports with millions of participants world wide e.g., American football, soccer, basketball, baseball, rugby, martial arts and ice-hockey (1-4). ATBI incurred in contact and collision sports can result in functional alterations which wary from transient cognitive impairments to death (5). Evidence of ATBI in contact and collision sports appears as temporary cognitive function loss, knock-outs, amnesia, postconcussion syndrome, subdural hematomas, headaches, and convulsions (5-9). 
Off all sports, boxing is associated with a large number of deaths and ATBI (7). Considering the objectwe of boxing competition to disable ones' opponent and render hirn nonfunctional, it is no surprise that ATBI can occur in boxing matches and sparring sessions. Jabs and blows to the head at an angle deliwer accelerationdeceleration, linear, and rotatory energy wectors that are likely to result in ATBI.

In addition to ATBI, chronic traumatic brain injury (CTBI) is of concern in boxing. CTBI due to contact and collision sports is often an insidious process which might start as mild subclinical dysfunction in the beginning of a career, detected only through neuropsychological investigation $(10-12)$, evolving into the slowed motor performance, tremors, cognirive deficits, personality change as seen in the 'punch drunk syndrome' (PDS), and psychiatric changes (13-17). The amount of ATBI received during the boxing cateer seems to be directly related to the severity of CTBI (5). This conforms to the model of cumulative effect which states that repeated blows to the head have an additive deleterious effect (18-19).

To get more understanding of ATB1 symptomatology the current investigation was undertaken to determine the presence and nature of ATBI, as evidenced by cognitive impaiment.

\section{Methods}

\section{Subjects}

"The inception cohort of this investigation consisted of 38 Dutch male amateur boxers and 28 male controls. The boxers who competed were selected at fight nights taking from every boxing bout at random one boxer. The boxers who served as controls were selected from four licensed Dutch boxing teams and frequency matched on boxing level, weight, age and education. All participants were native Dutchen and educated in the Dutch educational system. Potential participants with a learning disorder, an alcohol consumption of more than fres intakes a week, concussions not related to boxing, drug use (soft and hard drugs) and medical conditions which might affect cognitive functioning as reported by their general practitioner were excluced. Data on age, weight, boxing skill and education were obtained in interviews. Weight was classified into three categories: light $(40-65 \mathrm{~kg})$, middle $(65-75 \mathrm{~kg}$ ), and heavy (>75 kg). Education was classified according to the Dutch Sccondary Schooling System: LBO (lower-, 10 years), MBO (middle-, 10 years), $\mathrm{HBO}$ (higher, 11 years). Boxing skill was ranked according to the system used by the Dutch Boxing Federation (N, C, B and A ranking). A ranked boxers are the most experienced fighters and won more than 12 matches, $N$ ranked boxers won 
fewer than 3 matches. The number of punches to the head was counted by reviewing the score cards of the ringside referees and then averaged. All the competitors used protective headgear during their fights conform to Dutch Boxing Federation regulation.

Comparisons were made between the amateur boxers who competed and the boxer controls who performed a bag punching task ( 3 rimes for 3 minutes each time). Trauma index variables regarding the number of matches fought prewiously, the time after the boxing match before the boxer was tested, impact (weight in combination with the total number of head punches incurred in the match), win - draw - or loss, ranking and special circumstances (knock-outs or technical knock-outs) were also documented. The technical knock outs scored in this study were situations that boxers showed symptoms of distress after being hit by head blows and were stopped by the referee. Distress by hits on the liver or for example stops for eyebrow cuts. were not classified as technical knock outs in this study.

\section{Neuropsychological Testing}

In the current investigation, neuropsychological tests that had proven sensitivity to cognitive impairment incurred in contact and collision sports $(4,11,19)$ were given. Each participant received before and after a boxing match or the bag punching rask. the same battery of neuropsychological tests administered by a trained psychometrician and an interview by a registered neuropsychologist. All tests were administered according to standardized instructions and procedures. Test responses were scored by a registered neuropsychologist who was blinded to the status (competitor or control) of the participant. The test battery included the following: Categorization Test (20), Paced Auditory Serial Addition Task (21), Digit Symbol (Wechsler Adult Intelligence Scale) (22), Trailmaking Test (A and B) (23), Stroop Test (interference trial, 24), Wechsler Memory Scale (WMS) subtests: Visual Reproduction and Logical Memory (25), and the Puncture Test (26). The Wechsler Memory Scale subtests were administered with an immediate and a 20 minutes delayed interval recall. One of the two subversions of the Logical Momory rest (WMS) was administered and for the visual memory part we selected the most complex form of the Visual Reproduction Test of the WMS. The competitors and boxer controls used the same version of these tests before and after competition or physical task. The Categotization Test is a word learning test which contains 9 different elements which can be classificd into three groups (fruit, vegetables, trees). The test can be divided in two different cognivive functions: a) word learning b) planning/organizarion. 


\section{Statistical analysis}

Comparisons berween the changes in neuropsychological testscores were performed by calculating the differences between the means and with the Student's tstatistic their confidence intervals and one-tailed $p$ values were determined. These comparisons were also performed with a linear regression analysis, adjusting for age, boxing skill, level of education, weight and time interval after excercise. To determine the association between boxing-related variables and change in test scores within the group of boxers who competed, adjusted regression coefficients and their $p$ values were calculated using a mutivanate linear regression model adjusting for the same variables.

\section{Results}

\section{Population Characteristics}

No significant differences between the two groups was found regarding the level of education $(p=0.67)$ and age $(p=0.37)$ (see Table 1). The control boxers had a shorter time interval after exercise than did the boxers after their fight $(p=0.053)$, this was not a significant difference (Table 1). Most of the boxers who competed were light $(47 \%)$ and middle weight $(32 \%)$ boxers. Twenty-one percent of the boxers in this study were heavy weight fighters. Most of the boxers were skilled fighters (N-level $24 \%$, C-level $26 \%$, A-level $50 \%$ ). Characteristics of the controls are presented in Table 1.

Table 1 Characteristics of boxers who competed and controls.

\begin{tabular}{|c|c|c|c|}
\hline & $\begin{array}{l}\text { Competing boxers } \\
\mathbb{N}=36\end{array}$ & $\begin{array}{l}\text { Controls } \\
\mathrm{N}=28\end{array}$ & P-Yalue \\
\hline \multicolumn{4}{|l|}{ Distrilination in \% over 3 levels of eduction: } \\
\hline low - midelle-high & $40-42-18$ & $41-30 \cdot 30$ & 0.67 \\
\hline \multicolumn{4}{|l|}{ Distributon ing o over 3 weight caregones: } \\
\hline light - niddle - heary & $4+32-21$ & $44-33-22$ & 0.83 \\
\hline \multicolumn{4}{|l|}{ Distriburion in \% over 4 levels of boxing skill: } \\
\hline $\mathrm{N} \times \mathrm{C} \cdot \mathrm{B}-\mathrm{A}$ & $24-26-0-50$ & $26-19-15-41$ & 0.75 \\
\hline Median age (range) & $22(18 \cdot 30)$ & $22(16-30)$ & 0.37 \\
\hline Median and ater interyenton in mus (sange) & & $5(1-20)$ & $4(1-15) 0,053$ \\
\hline
\end{tabular}

Mann-Whitney test 


\section{Traumatic Exposure in an Amateur Boxing Match}

The median number of head punches sustained during an amateur boxing match was 8 (range 0-31). Sixty five percent of the boxers received 10 or fewer head punches and $35 \%$ of the boxers incurred more than 10 head punches in a match. Concussions with or without loss of consciousness were a frequent occutence in amateur boxing matches. Thitteen percent of the fights ended in a knock-out (concussive state with loss of consciousness) or referee-stops-contest-head (RSCH) decision (concussive state without loss of consciousness, e.g, when the boxer was not able to continue the fight due to mental impaiment?.

\section{Neuropsychological testing}

Table 2 shows the means of the testscores and their unadjusted differences. All the tests were also analysed using a multivariate linear regression model adjusting for time after match/physical task, level of education, weight category and level of boxing skill. The results differed only marginally. Boxers who competed exhibited more cognitive impairments on tests of planning, attention, and memory compared to controls. On a number of tests significant differences were found e.g., Categorization Test $(p=0.04)$, Logical Memory STM $(p<0.001)$, LTM $(p<0.001)$ Visual Reproduction STM ( $p<0.001)$, LTM $(p=0.003)$ and Digit Symbol $(p=0.02)$.

No significant differences were found in tests of speed of information processing. (PASAT (3.2 condition, $\mathrm{p}=.413$ ) or attentional efficiancy (Stroop Interference Card: speed $p=0.07$, number of mistakes $p=0.5$ ).

Tests requiring fine motor behavior proved to be invalid for this study due to the very large intersubject variability on these tests. Both controls and competitors punched with both hands. The heaviest blows in matches and training are delivered by the dominant hand, which introduced greater intersubject variability in dominant hand performance. As a consequence the standard deviation of the Puncture test (fine motor behavior) is an example. The standard deviation was high for the dominant hand but not for the non dominant hand. 
Table 2 Mcan change in test score in boxers who competed and in control boxers who performed a physical task, the difference of the changes with its $90 \%$ Confidence Interval and one talled $\mathrm{p}$-value if $\mathrm{p}<0.05$.

\begin{tabular}{|c|c|c|c|}
\hline & $\begin{array}{l}\text { Change in scores in } \\
\text { comaperting boxers }\end{array}$ & controls & $\begin{array}{l}\text { Difference in change } \mathrm{P} \text { value } \\
(90 \%-\mathrm{Cl})\end{array}$ \\
\hline \multicolumn{4}{|l|}{ Categorization task } \\
\hline numbers remenbered & -005 & 0 & $-0.05(-0.67$ to 0.57$)$ \\
\hline number of categories & -0.08 & +0.19 & $-0.27(0.540-0.003) 0.047$ \\
\hline PASAT & -1.22 & 1.17 & $-0.06(-2.27$ to 2.16$)$ \\
\hline \multicolumn{4}{|l|}{ Puncture test } \\
\hline dominant hand & +3.00 & +5.31 & $-231(-6.41$ to 1.80$)$ \\
\hline non-dominant hand & +5.24 & +6.76 & $-1.52(-6.38$ to 1.76$)$ \\
\hline \multicolumn{4}{|l|}{ Stroop Interference Catd } \\
\hline number of seconds & -7.16 & -7.65 & $\# 0.91(-6.48$ to 7.46$)$ \\
\hline number of mistakes & -0.24 & -0.62 & $+0.43(-0.42$ to 1.17$)$ \\
\hline Digit Symbol & +5.66 & +9.38 & $-3.73(-6.63$ to -0.82$) 0.02$ \\
\hline \multicolumn{4}{|l|}{ Trailmaking Test } \\
\hline Form $A$ & -4.42 & $-3,63$ & $-0.79(-3.24$ to 1.66$)$ \\
\hline Form $\mathrm{B}$ & -9.45 & -11.27 & $+1.82(-3.59$ to 7.23$)$ \\
\hline \multicolumn{4}{|l|}{ Logicall Mernory (stoties) } \\
\hline subtest WMS, STM & -1.19 & +1.52 & $-2.71(-3.75 \times-1.66)<0.00$ \\
\hline subtest WMS, LTM & -1.17 & +1.70 & $-2.87(-3.87$ to -1.86$)<0.001$ \\
\hline \multicolumn{4}{|l|}{ Visual Reproduction } \\
\hline subtest WMS, STM & -1.39 & +0.04 & $-1.43(-1.49$ to -0.88$)<0.00$ \\
\hline subtest WMS, LTM & -1.05 & $-0,11$ & $-0.94(-1.49$ to -0.40$) 0.003$ \\
\hline
\end{tabular}

\section{Intra-group comparison in competitors}

Some traumatic exposure variables have a negative impact on cognitive function. Impact (weight in combination with the number of punches) is reducing the number of categories $(p=0.03)$ and number of elements reproduced in a visual memory STM task $(p=0.02)$. Knock outs and technical knock outs $(R S C-H)$ reduced the number of elements remembered in a verbal memory task $(p=0.03)$. Lower ranked boxers ( $N$ and $C$ skilled boxers) showed a slower response in the Stroop reading card $(p=0.01)$ compared to $A$ ranked boxers. Remarkable is a better performance of the non-dominant hand in boxers who sustained a knock out $(p=0.04)$. No statistical differences in test performance was found between winners, losers or boxers with a draw. 


\section{Discussion}

There is a high risk for ATBI in amateur boxing competition. Despite the use of protective headgear, the brain is still susceptible to ATBI in amateur boxing. ATBI typically involves impaiments in planning, attention, and memory. Our findings are in agreement with those of Critchlley (27) who reported memory problems in boxers who sustained an ATBI (knock-out or technical knock-out). Furthermore, Kelly et al (7) documented attention and memory problems as acute symptoms in athletes who sustained concussions with or without loss of consciousness.

In this inception cohort study, several methodological precautions were taken to minimize the problems associated with group comparisons. Cultural and educational differences were eliminated; drug use, more than five alcohol intakes a week, leaming disorders and medical conditions that could affect cognitive functioning served as exclusion critetia. Controls were frequency matched on age, boxing skill and weight category thus implicitly controlling for variables concerning previous boxing experience as concussions sustained in previous fights and the number of fights. Furthermore, the influence of possible confounders was limited by using the individual banges in cognitive functioning as outcome. Physical activity vartables were essentially equated for the two groups of boxers. Assessment and scoring procedures were controlled for expertise and bias. Difference in mental, physical and emotional status could also explain these results. Boxers who competed fought a real match which evokes a 'fight' response in plyysical, cognitive and emotional systems. It proved to be difficult to control for these arousal variables which would be unlikely to affect the bag punchers.

ATBI in amateur boxing appear to be related to concussions, subconcussive blows, and trivial traumata associated with the impact of head punches. The amateur boxers in the curtent investigation sustained a medinn of 8 head punches during the match. and $13 \%$ of the matches ended in concussions with or without lloss of consciousness. Impact (weight in combination with the number of punches) of the blows delivered to the opponent in the match, knock outs and technical knock outs were predictors for cognitive functioning after a match (impairment in memory and planning abillity).

Depression (losing the match) was not an important predictor, this study showed no significant differences in newropsychological test scores between winners, losers or bosers who boxed a draw. Moreover, cognitwe symptoms of ATBI (planning, attention, and menory problems) resemble those of CTBI. Thus it is plausible that athletes who incur repeated ATBI do not fully recover from these injuries and that 


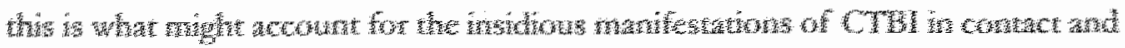

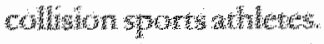

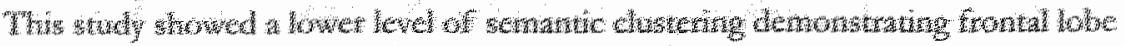

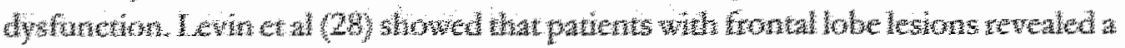

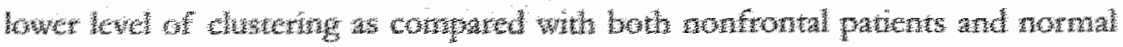

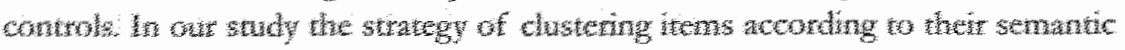

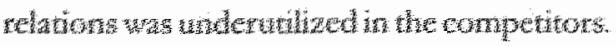

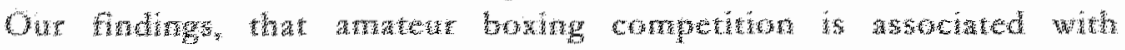

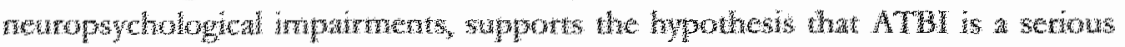

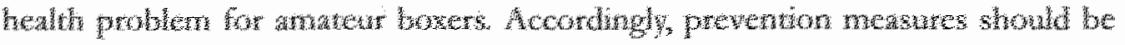

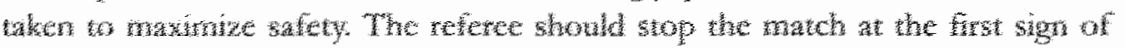

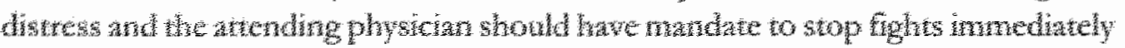

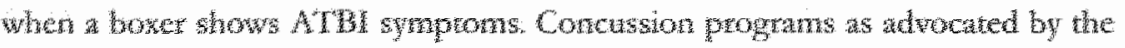

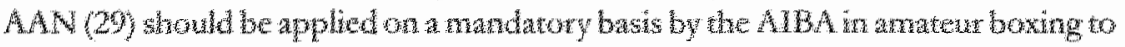

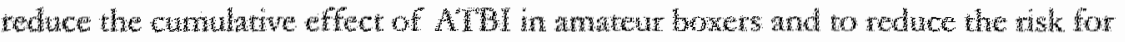

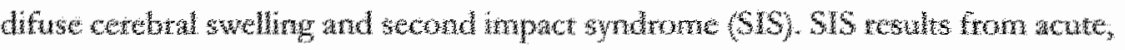

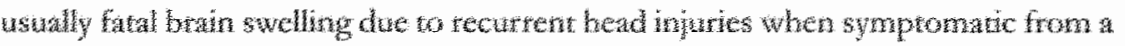

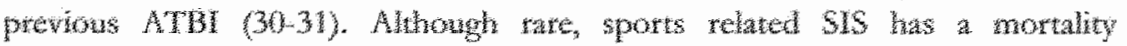

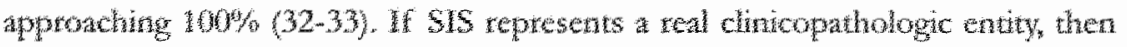

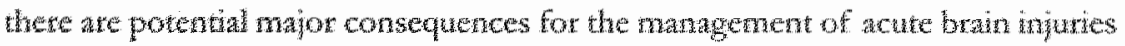
in anateur and protessional boxng. The Standardized Assesment of Concussion (SAC) as proposed by McCrea (34) and the test stategy to detect symproms of concussion as poposed by Madacts (35) et al (995) are reasonable procedutes for assessment of ATB in amatew and professional boxing. As our shey shows visual memory tests should be added in the SAC. Visual memory tests are easy to adrinister and beside visual memory performance it gives the physician an impression of phaning capacity.

\section{Conclusion}

Participation in amateur boxing matches may adversely affect cognitive functioning (.e, planring, attention and memory) despite the use of protective headgear. This impairment in neurocognitive function appears to be attributable to the itrpact and number of head punches and concussions with or whont loss of consciousness causing ATBI. Guidelines are recommended to reduce cumulations of ATBD and the risk for SIS.

The duration and course of ATBI symptoms (eg, attention, memory and planning) coukt not be documented in this study but are important issues for further research. Whether our frndings can be extrapolated to other contact sports like socer and American football remains to be determined in future investigations. 


\section{References}

\section{Chapter 2}

1. Jordan B. Sports Inijures. In: Proceddings of the mild brain injury in sports Summit. Dallas, TX: National Athletic Trainers Association, Inc, 1994; $43-46$.

2. Ommaya $A$, Ommaya $A$ and Salacar A. A specrum of mild brain injuries in sports. In: Proceedings of the mild brain injury in spors Summir, Dallas, TX: Nacional Adlletic Trairuers" Association, Inc, 1994; $72-80$.

3. Bodesi B, Kirkendall D, Garrett W. Concussion incidence in elite college soccer players. American Journal of Sports Medicine 1998; 26: 238241.

4. Matser J, Kessels A, Jordan B, Lezak M, "Troost J. Chnonic Tramatic Brain Injary in Protessional Soccer Players. Neurology 1998; 51: 791-796

5. Jordan B. Boxing. In: Jordan B, Tsauris P, Warren R, eds. Sponts Neurology, second edition. Philadelphia: Lippincot-Raven 1998; 351-367.

6. McCunney $R$, Russo P. Brain injuries in boxers. The Physician and Sportsmedicine 1984; 12: 5367 .

7. Kelly JP Rosenberg JH. Diagnosis and management of concussion in sports. Neurology 1997 ; 48: $575-580$.

8. Evans $\mathbb{R}$. The post concussion syndrome and the seguelae of mild head injury. Neurology Clinics $1902 ; 10$; $815-847$.

9. McCrory P, Bladin P. Berkovic S Retrospective study of convulsions in elite Australian rules and rughy league footballers: phenomenology, ctiology and outcome. Britsh Medical Journal 1997; 24:25-38.

10. Drew R, Templar D, Schuyler H, Newell T, Cannon W. Neuropsychological deficits in active licensed professional boxers. Journal of Clinical Psychology \1986: 42: 520-525.

11. Matser JT, De Bijl MAO, Lujitelaar ELJ. Is amatenmboxing dangerous? De Psycholoog 1992; 12:515-521.

12. Gronwall $D$, Wrightson $P$. Delayed recowery of intellectual function after minor head injury. Lancet 1974: $14: 605 ; 609$

13. Roberts A. Brain damage in boxers. London:Pitman Pubishing, 1969

14. Martand H. Punch drunk JAMA 1928; 91: 1103-1107.

15. Johrason J. Organic psychosyndromes due to boxing British Journal of Psychiatry 1969; 115: 4553 .

16. Haghund $Y_{3}$ Frikson $E$. Does anateur boxing lead to chronic brain damage? A revicw of some recent investigations. American Journal of Sports Medicino 1993; 21: 97 109.

17. Mendez M. The neutopsychiatric aspect of boxing Int Psychiatry Med 1995: 25: 249-262.

18. Gronwall D, Wrightson $\mathbb{P}$. Cumutative effect of concussion. Ilancet 1975; 22: 995.997.

19. Jordan $\mathrm{B}_{\mathrm{s}}$ Matser $\$, Zazula T. Sparring and cognitive functioning in professional boxers. "The Physiciara and Sportsmedicine 1996;24:87.98.

20. Categorization Task. In: Kolb B, Whishaw I. Fundamentals of Human Netropsychology. New York: Frecman and Company 1990; 451.

21. Gronwall D. Paced Awditory Serial Addition Task: A measure of recovery from concussion. Perceptual and Motor Skills 1977; 44:367-373.

22. Wechlser D. WA1S-R Manual New York: The Psychological Corporation, 1981

23. Spreen O, Strauss E. A compendum of neuropsychological tests Now York Oxtord Uniersity Press, 1991. 
24. Golden CI Stroop Color and Word Test Chicago: Stoelling 1978.

25. Wedysler D. Wechisler Memory Scale Manual. San Antonio: The Bsychological Comporation. 1974.

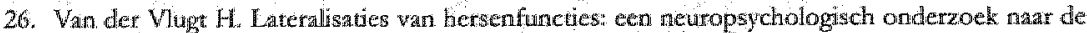
relate trissicn handwootkeur en de relate van de talfunctie. Lisse: Swets \& Zeitlinger 1979.

27. Critchley Medical aspects of boxing particilarly from a neurological standpoint. British Medical Journal 1957; 1:357-362.

28. Levin $\mathrm{H}$, Goldstein, $F$, Walliams $\mathrm{D}$, Eisenberg. $\mathrm{H}$. The contribution of fronal lesions to neurobehwitoral outcome of closed head injury. In Lewin $\mathbb{H}$, Fisenberg $H$, Benton $A$, eds. Frontwil lobe function and dysfunction. New York: Oxford Unwersity Press, 1991; 318-338.

29. Quality Standards Subcommittee. Practice Parameter: The management of concussion in sports. Newrology $1997 ; 48: 581-585$.

30. Kelly JP, Nichols IS, Fulley CM, Lillehei KO, Rubinstein D, Kleinschmidt-DeMaster BK Concussion in sports: guidelines for the prevention of catastophic outcome JAMA 1991; 266: $2867-2869$.

31. Cantu $\mathrm{RC}_{3}$ Voy R. Second impact syndrome: a täsk in any contact sport. The Physian and Sportsmedieine 1995; $23 ; 27-34$.

32. MeQuillen JB, McQuillen EN, Morrow P. Trauma, sport and maligrnant cerebral edema. American Journal of Forensic Medical pathology 1988; $9: 12-15$.

33. Saunders RL, Harbaugh RE, The second impact in catastroplic contact-sports head trauma. JAMA $1984 ; 252: 538-539$.

34. McCtea M, Kely MD, Kluge Jo Ackley B, Randolph C. Standardized assessment of concussion (SAC) in football players. Neurology 1997; $48: 586 m 588$.

35. Maddocks DL, Dicker GD, Saling MM. The assessment of orientanion following concussion in athletes. Clin J Sports Med 1995; 5: 32-35. 
Chapter 3

\section{Neuropsychological impairment in amateur boxers*}

JT Matser, MAO de Bijl, ELJ Luijtelaar

* Modified from Matser JT, De Bijl MAO, Luijtelaar G. Is amateurboxing dangerous? De Psycholoog 1992; 12: 515-521. 


\section{Introduction}

There is little empirical evidence that amateur boxing can cause brain damage. The few studies in amateur boxers published yet (1-3) show no association between boxing and neurologial dysfuctions. However, the research done on professionals and ex-professionals suggest a positive correlation between the duration of the boxing career and the intensity of cerebral damage, particularly temporal and frontal brain damage (4-7). Furthermore, most research lacks a neuropsychological evaluation specific for symptoms associated with tramatic brain injury. In the past few years it is becoming clearer that these subtle cognitive defects, which can not always be recognized by means of a neurological examination, can be detected with neuropsychological assessment (8). In the present research it will therefore be examined, by means of neuropsychological research, if amateur boxers show signs of brain damage. It will in particular be examined whether a dose (number of matches)-response (intensity of impairment) relation can be detected. The choice of tests is particularly motivated by the literature on closed head injury (9).

\section{Methods}

\section{Subjects}

All boxers participating in this study, were members of a boxing club affiliated to the Dutch Boxing Federation (NBB). A doctor member of the Medical Commission of the $\mathrm{NBB}$ approached a number of coaches with the request to ask their pupils to participate. 'The coaches were also asked to select boxers who fought from 5 to 16 matches (16 boxers) and equal to or more than 30 matches (17 boxers). The boxers were asked if they could bring a non-boxing friend on the day of the tests, who were used as a control $(n=6)$. The other controls $(n=10)$ were recruited from the new members of the local boxing club who had never sparred before. None of the controls had a prehistory of brain damage or drug abuse. The three groups were matched on age and education. All participants were native Dutchmen and educated in the Durch system. Potential participants with a learning disorder, an alcohol consumption of more than 5 intakes a week, concussion not related to boxing, medical conditions which might affect cognitive functioning as reported by their general practitioner were excluded.

Of all participants age, education ( 1 stands for highschool only and a 6 for academic or higher vocational education level) and if applicable number of matches (lost, draw or won) and duration of boxing career, were registered. 


\section{Neuropsychological tests}

The test battery consisted of a few subtests of the WAIS (intelligence test) (10), the Wisconsin Card Sorting Test (measures a form of abstract thinking, parriculaty the exchange of solving strategies) (11), the word fluency test of the Groninger Intelligence Test (measures the speed and facility of verbal production and the long. term memory) (12), the Wechsler Memory Scale I WMS) (with which wrious aspects of memory can be tested and word associations can be learned and memorized) (13). The Complex Figure Test (short and longterm memory for visual-spacial information) (14), attention and concentration tasks (the Trail Making $A$ and $B$ (15) and the Stroop Color Word Test) (15), the Figure Detection test of the Groninger Intelligence test (perceptual observation and memory) (12) and the Puncture test (fine motor behavior) (16). The Complex Figure Test consists of three phases. First the boxer is asked to redraw a map, this is to measure the perceptual organization. After completing the rask, unexpectedly, the boxer is asked to reproduce the figure, however without the original (STM visual memory). Twenty minutes later the boxer is asked again to draw the figure (LTM visual memory). The majority of the tests used are explained in Lezak (9).

\section{Statistical analysis}

The differences between the three groups have been tested with variance analysis with the number of matches ( 0 , from 5 to 16 and more than 29 matches) as factor. If a significant effect was found, the differences between the three groups were tested with a post hoc test according to Scheffé. Also, the $25^{\prime \prime}$ percentile score of ench test was calculated.

Table 1 Boxing experience, age and education.

\begin{tabular}{|c|c|c|c|c|c|}
\hline Numbet of boxing matches & 0 & & $5-15$ & & 231 \\
\hline Age & 24.0 & \pm 4.8 & 22.8 & \pm 4.6 & $24.1+4.5$ \\
\hline \multicolumn{6}{|l|}{ Number of boxing matches } \\
\hline Won & " & & 6.5 & \pm 25 & $36.5 \pm 8.6$ \\
\hline Lost & .". & & 3.2 & \pm 2.2 & $13.7+8.6$ \\
\hline Draw & - & & 0.6 & \pm 0.9 & $42 \pm 2,6$ \\
\hline Boxing experience in years & - & & 5.2 & \pm 2.4 & $8.6 \pm 3.9$ \\
\hline Bducation (wecording to Verhage) & 5.5 & \pm 1.8 & 5.1 & \pm 2.2 & $5.2 \pm 2.2$ \\
\hline
\end{tabular}




\section{Results}

The three groups did not differ significantly in age and education. The Complex Figure Test (immediate and delayed recall) showed differences in memory performance between the three groups. Nil, four and nine controls from respectively the control group, the 5 to 16 matches group and the more than 29 matches group performed under the $25^{*}$ percentile scote; boxers who boxed more than 29 matches performed significantly worse on these tests than the control group. Also on the Stroop card 2 (name colors) boxers with more than 29 matches scored significantly worse than the control group. The ANOVA showed significant differences in the Trail Making A test scores.

\section{Discussion}

These findings suggests that participating in amateur boxing may be associated with neuropschological impaiment. A relationship was (found between an increasing number of boxing matches and adecline in memory and attention performance.

In our study, several methodologic precautions were taken to minimize the problems associated with group comparisons. All the participants in this study were native Durchmen and educated according to the Dutch educational system therefore climinating misinterpretations caused by educational differences. In addition, the three groups were matched on age and education and potential participants with a history of drug and alcohol abuse, learning disorders and neurological complaints not caused by boxing were excluded.

The Complex Figure Test (immediate and delayed recall), "Trailmaking $A$ and the Stroop test (the colour naming card) detected symptoms of neurocognitive impairment in amateur boxers. An increasing number of boxing matches was negatiwely associated with scores on these tests. These findings are in agreement with those of Matser et al $(17)$ who showed a higher degree of memory impairment in association with a greater exposure time in sparring This memory impaiment can be related to diffuse brain damage as well as to the right posterior temporal lobe parhology (18). In addition, the copying score on the Complex Figure Test did not differ significantly between the groups suggesting that the visual organisation of the boxers was not abnormal. 
Table 2 Psychometric performance of controls, boxers with 5 up to 16 matches and boxers $>29$ matches. The mean writh the standard deviation is shown.

\begin{tabular}{|c|c|c|c|c|c|}
\hline Number of boxing matches & $\overline{0}$ & $5-1 \overline{5}$ & & $>30$ & \\
\hline \multicolumn{6}{|l|}{ WAIS subtest } \\
\hline Digit symbol & $59.6 \pm 11.4$ & $54.2 \pm$ & 6.2 & $52.7 \pm$ & 8.6 \\
\hline Similarities & $19.9 \pm 4.2$ & $17.1 \pm$ & 6.2 & $16.7 \pm$ & 5,6 \\
\hline Block Design & $20.9 \pm 6.1$ & $20.3 \pm$ & 6.1 & $17.9 \pm$ & 5.5 \\
\hline Vocabutary & $34.3 \pm 9.3$ & $32.9 \pm$ & 12.1 & $27.8 \pm$ & 12.2 \\
\hline \multicolumn{6}{|l|}{ Complex figure test } \\
\hline Copy & $35.4 \pm 0.8$ & $34.2 \pm$ & 3.2 & $34.0 \pm$ & 1.7 \\
\hline Immediate recall & $23.3 \pm 3.3$ & $20.3 \pm$ & 7.1 & $15.8 \pm$ & 7.4 \\
\hline \multicolumn{6}{|l|}{ Wechsller memory scale* } \\
\hline Visual memory & $15.4 \pm 0.8$ & $17.5 \pm$ & 1.0 & $17.3 \pm$ & 0.8 \\
\hline Logical memory A & $7.2 \pm 1.8$ & 8.0 & 2.6 & $8.1 \pm$ & 3.6 \\
\hline Logical memory $B$ & $6.1 \pm 2.7$ & $6.5 \#$ & 3.1 & $8.2 \pm$ & 3.5 \\
\hline Digits (forward and backwards) & $11.1 \pm 1.2$ & $10.9 \pm$ & 1.0 & $9.4 \pm$ & 1.1 \\
\hline Mental control & $8.2 \pm 0.4$ & $7.5 \pm$ & 0.5 & $7.6 \pm$ & 0.5 \\
\hline Associate leatring & $16.2 \pm 3.3$ & $17.5 \pm$ & 3.4 & $16.9 \pm$ & 3.2 \\
\hline \multicolumn{6}{|l|}{ Filuency (GIT) } \\
\hline Animals & $29.8 \pm 8.1$ & $27.4 \pm$ & 6.2 & $26.3 \underline{4}$ & 5.4 \\
\hline Professionals & $23.2 \pm 5.0$ & $23.2 \pm$ & 6.2 & $224 \pm$ & 6.6 \\
\hline \multicolumn{6}{|l|}{ Traillmaking } \\
\hline A & $20.6 \pm 5.3$ & $26.1 \pm$ & 8.8 & $26.7 \pm$ & 7.4 \\
\hline$B$ & $58.8 \pm 29.6$ & $64.2 \pm$ & 16.1 & $60.8 \pm$ & 15.0 \\
\hline \multicolumn{6}{|l|}{ Stroop } \\
\hline Card 1 (reading) & $40.7 \pm 7.1$ & $43.7 \pm$ & 5.9 & $44.7 \pm$ & 4.7 \\
\hline Card 2 (color maming) & $52.7 \pm 9.3$ & $60.2 \pm$ & 8.6 & $61.9 \pm$ & 9.1 \\
\hline Card 3 (interfence) & $86.5 \pm 21.9$ & $93.1 \pm$ & 15.6 & $100.5 \pm$ & 18.5 \\
\hline \multicolumn{6}{|l|}{ Wisconsin card sorting test } \\
\hline Number of shifos & $4.7 \pm 1.4$ & $5.2 \pm$ & 1.2 & $4.1 \pm$ & 1.5 \\
\hline Figure detection score & $15.9 \pm 2.4$ & $16.2 \pm$ & 3.0 & $15.4 \pm$ & 2.7 \\
\hline \multicolumn{6}{|l|}{ Puncture test } \\
\hline Dominant hand & $98.5 \pm 5.3$ & $96.5 \pm$ & 5.6 & $94.1 \pm$ & 7.9 \\
\hline Non dominant hand & $74.9 \pm 31.7$ & $76.4 \pm$ & 22.3 & $72.4 \pm$ & 211 \\
\hline
\end{tabular}

* "Toral sum of all scales (included delayed recall)

t significant difference according to scheffé between $>25$ and controt group ( $\mathrm{p}<00)$ + significant difference according to Seheffe between $>29$ and control group $(\mathrm{p}<05)$ 10 significant experience effect according to the ANOVA analysis. 
It was remarkable that boxers with a high number of matches only performed badly on the complex memory tasks (Complex Figure Test) and not on the simple memory tasks (WMS). This seems to correspond with the tesults published by Brooks (19). This research group did not find significant differences between amateur boxers and a control group on scores of the WMS subtests.

The results of the Trailmaking $A$ and the Stroop Card 2 indicate that boxers with more than 29 matches are obstructed by attention and concentration problems. However, these results can also be interpreted as a starting problem indicative for frontal lobe pathology or brain damage in general. In this explanation the organization of a cognitive schedule is delayed (20) and the patient needs more time to organize tesponses that are needed for the realization of a neuropsychological test.

This study demonstrates that amateur boxers, in the long run, sustain neuropsychological impairments. Prevention guidelines should be developed by the official boxing bodies (EABA, AIBA) to protect amateur boxers for cognitive deterioration.

\section{References}

\section{Chapter 3}

Netropsychological impairment in amateur boxers

1. Erikson E. Does amateurboxing cause brain damage? Circular or 12 of the Euiropean Amateur Bioxing Association (EABA), 1984.

2. Levin HS, Lippold SC, Goldman A. Neurobehavioral funcrioning and magnetic resonance imaging in young boxcrs. Journal of Neurosurgery 1987; 67: 657-667.

3. Jordan $\mathrm{BD}$, Zimmerman $\mathrm{RD}$. Magnetic resonance in amatetir boxers. Archives of Neurology 1988; $45: 1207-1208$.

4. Jordan BD, Zimmerman RD. Computer tomography and magneric resonance imaging comparisons in boxers. fournal of the American Medical Association 1990; 263: 16701674

5. Casson 1R, Siegrel $O$, Sham $R_{8}$ Campbell EA, Tarlau $M$, Dimomenico $A$. Brain danage in modern boxers. Journal of the American Medical Association 1984; 251: 2663-2667.

6. Ross RJ, Cole M, Thompson JS, Kim KH. Boxers, computed tomography, EEG and newrological evaluation, Journal of teh American Medical Association 4983; 249:211-213.

7. Robberts AH. Brain damage in boxers. London: Pitnaan Medical Scientife Publishing Co, 1969.

8. Wan Zomeren AH. Reaction time and attention after closed head injury. Lisse: Swets \& Zeitlinger, 1981.

9. Lezalk MD. Neuropsychological Assessment. New Yotk: Oxford University Press, 1983.

10. Wechlser D. WALS-R manual New York: The Psychological Corporation, 1981.

11. Berg $\mathrm{EA}$. A simple objective trentment for mensuring tlexibiliry in thinking Journal of General Psychology $1948 ; 39: 15-22$.

12. Luteyn F een nieuwe verkorte GiT. Dutch Journal of Psychology 1966; 2: 675-682.

13. Wechlser D. Wechlser Memory Scale mantal. San Antonio: The Psychological Corparation, 1974. 
14. Osterieth PA. Le rest de copie d'un

15. O Strauss E. A compendium of neuropsychological tests. New York: Osford University Press, 1991.

16. Van der Vlugt H. lateralisanes wan hersenfuncties: een neuropsychologiseh onderzoek naar de relatie tussen handwoorkeur en de relatie wan de talfunctie. Lisse: Swets \& Zeitlinger, 1979 ,

17. Matseir JT. de Biil MAO, Luigtelaar ELJ, Jondan BD. Neuropsychological functioning in active amateur and professional boxers. Paper, 20th INS meering, San Diego, USA, 1992

18. Kolb $\mathbb{B}$, Whisaw IQ. Fundamentals of $\mathbb{H}$ uman Neuropsychology New York: Freeman and $\mathrm{Co}$, 1985.

19. Brooks $N_{s}$ Kupshik $G_{x}$ Wilson $L_{n}$ Galbraith $S$, Ward R. A neuropsychological study of active amateur boxers. Journal of Newrolog;, Neurosurgery and Psychiatry 1987; 50: 997-1000.

20. Tromp E, Mulder T. Slownesss of information processing aher trammatic head injury. Journal of Cinicall and Experimental Neuropsychotogy $1991 ; 13 ; 821.830$. 
Chapter 4

\section{Neuropsychological impairment in amateur soccer players*}

JT Matser, MSc (1), AG Kessels, MD (2), MD Lezak, PhD (3), BD Jordan, MD (4), $\int$ Troost, $\mathrm{MD}(5)$.

1. Department of Neuropsychology and Sportsneurology, St Anna Hospital Geldrop, The Netherlands.

Department of Anatomy, Erasmus University Rotterdam, Faculty of Medicine and Heal th Sciences, The Netherlands

2. Research Unit Patient Care, University Hospital of Maastricht, The Netherlands

3. Deparment of Neurology, Oregon Health Science University Portland, USA

4. Traumatic Brain Injury Program, Burke Rehabilitation Hospital, White Plains, New York, USA

5. Department of Neurology, University Hospital of Maastricht, The Netherlands 


\section{Abstract}

Context: Soccer players incur concussions during matches and training sessions, as well as numerous subconcussive blows to the head from impacts with the soccer ball (headers). The combination of soccer-related concussions and the number of headers may be a risk for chronic traumatic brain injury (CTBI).

Objective: To determine whether soccer players have evidence of CIBI.

Design, Setting, and participation: Cross-sectional study of 33 amateur soccer playerts and 27 amateur athletes involved in swimming and track (controls) in the Netherlands who underwent interwiews and neuropsychological testing.

Main Outcone Measures: Performance of soccer players vs controls on 16 neuropsychological tests having 27 outcomes.

Resuls: Compared with control athletes, amateur soccer players exhibited impaired performance on tests of planning $(39 \%$ vs $13 \% ; \mathrm{P}=.001)$ and memory $(27 \% \mathrm{vs} 7 \%$; $\mathrm{P}=004)$. Among soccer players, $9(27 \%)$ had incurred 1 soccer-related concussion and $7(35 \%)$ had had 2 to 5 concussions during their career. The number of concussions incurred in soccer was inversely related tot the neuropsychological performance on 6 of the neuropsychological tests.

Conclusions: Our results indicate the participation in amateur soccer in general and concussion specifically is associated with impaired performance in memory and planning functions. Due to the worldwide popularity of soccer, these observations may have important public heall th implications.

Key words: Chronic Traumatic Brain Injury, CTBI, Soccer

\section{Introduction}

Chronic traumatic brain injury (CTBI) is the cumulative long-term neurologic consequence of repetitive concussive and subconcussive blows to the head, and has been described primarily among professional boxers (1-4). Evidence suggests that CTBI also may be associated with professional soccer (5-6). Neuropsycholegical impairment and neurological abnormalities have been observed in retired amateur and active professional soccer players (7-11). A surwey of active soccer players reported that neurological symptoms correlated with reported history of acute head injury received during play (12). To date, only 1 preliminary investigation evaluated 
neuropsychological functioning in nonprofessional high school soccer players (13) The current investigation was undertaken to determine if neuropsychologica dysfunction occurs in amateur soccer players.

\section{Methods}

Between September 1997 and May 1998, athletes from 3 complete teams of : different regional-league amateur soccer clubs $(n=33)$ wete compared with 2 : control athletes. The control athlctes were middle-distance runners ( 2 complet premier-league track teams) and middle distance swimmers (1 complete premier league team) from the same region as the soccer clubs. All participants completed ar interview that inquired about age, education, lifetime number of general anesthesias occupational history, ]earning disorders, life-time number of concussions (sports. and nonsports-related), alcohol intake, drug use, and medical conditions that migh affect cognitive functioning. The primary physicians for all participants wer interviewed regarding the number of concusstons athletes had incurred and medica conditions that might interfere with cognitive functioning. All participants in this study were native to the Netherlands and educated in the Dutch educational system A thletes also excluded for history of drug use, learning disorders, epilepsy, and othes medical conditions that might affect cognitive funcioning. Education was scored or a 7-point scale and because all participants completed their secundary schoo. education, only the level 3 (technical and vocational training for ages $12-16$ years) to level 7 (academic) were used. This study was approved by the St. Anna Hospita Medical Ethical Committee and oral informed consent was obtained from al particiapants.

Each participant was interviewed by a neuropsychologist and receivec neuropsychological tests administered by an experienced psychometrician. All tests were administered according to standardized instrucrions and procedures. The test data were scoted by a neuropsychologist who was blinded to the status of the participant. The neuropsychological tests included the Raven Progressive Matrices (14), Wisconsin Card Sorting Task (15), Paced Auditory Serial Addition Task (16). Digit Symbol Modalities test (17), Trail-making $A$ and $B$ (18), Stroop test (19) Bourdon-Wiersma test (20), Wechsler Memory Scale (21); (Associate Iearning Logical Memory, and Visual Reproduction subtests), Complex Figure Test (22), 15 . Word Learning Test (23), Benton Facial Recognition Test (24), Figure Detection Tes: (25), Verbal Fluency Test (25) and the Puncture Test (26). 
The means of the neuropsychological test scores were compared using the t test; with 1-tailed $P$ values. The differences, their confidence interwals, and 1-talled $P$ values were determined with a linear regression analysis adjusting for level of education, alcohol intake, number of general anesthesias, and number of concussions not due to soccer play.

Multiple end point testing was controlled for by clustering the 27 test scores into 8 cognitive functions as described by Lezak (27). For each cluster, a global null hypothesis stating that all differences of the included test scores are 0 was tested using the ordinary least squares (OLS) test (28-29). For the 8 resulting one-tailed P walues, a Bonferroni correction for the significance level was applied. In addition, the means of the neurocognitive tests scores among the soccer players were analyzed. Soccer players with and without soccer-related concussions were compared using the t test.

\section{Results}

Soccer players were similar to controls in age, education, nonsoccer related concussions, and number of times they had recieved general anesthesia (Table 1). The soccer players exhibited a higher frequency of alcohol intake per month compared with controls.

Table 1 Characteristics of soccer players and controls.

\begin{tabular}{|c|c|c|c|}
\hline & Soccer players & Controls & 2 talled $P$ value \\
\hline Number & 33 & 27 & $\ldots *$ \\
\hline Age: tmean (sd) & $24.9(4.2)$ & $24.5(4.5)$ & 0.95 \\
\hline Level of education: median (range) & $5(4-6)$ & $5(3-7)$ & 0.53 \\
\hline $\begin{array}{l}\text { Number of aloohol thathes per mon } \\
\text { median (range) }\end{array}$ & $50 \quad(0-99)$ & $28 \quad(0.99)$ & 0.02 \\
\hline $\begin{array}{l}\text { Wumber of general anaesthesias: } \\
\text { median (range) }\end{array}$ & $1 \quad(0-4)$ & $0 \quad(04)$ & $0.111^{\prime}$ \\
\hline $\begin{array}{l}\text { Percentage of persons with one } \\
\text { concussion not sustanted in soccer }\end{array}$ & 27.3 & 14.8 & $0.55^{\mathrm{m}}$ \\
\hline
\end{tabular}

* Ellipses indicate dara not applicable. Dnta were calcullated using the t test.

Education level is based on a Dutch 7-point scale.

Data werc calculated using the Mann- Whitney test.

- Daita were calculated using the Fisher exact test.

No subject experienced more than $\mathbb{1}$ concussion in their litetime. 
The awerage dutation of an amateur career was 17 years. Thirty-three percent played 5 to 15 years and $67 \%$ olayed more than 16 years. The average time spent in training practices was $3.6 \mathrm{~h} /$ wh and the median of the number of matches played annually was 36 (range $20-70$ ). The median number of balls headed in a match was 8.5 (range, 0-20). Nine playerss ( $27 \%$ ) incurred 1 soccer-rellated concussion; 7 players (23\%) reported 2 to 5 concussions in a careet.

Amateur soccer players exhibited impairment in planning (OLS $\mathrm{P}=.001$ ) and memory (OLS P =.004) (Table 2). These scores remained statistically significant after Bonferroni correction. After adjusting for concussions unrelated to soccer, alcohol intake, level of education, and number of general anesthesias, soccer players performed significantly poorer (1-tailed $\mathrm{P}<.05)$ on the Complex Figure Test (Immediate Recall $[\mathrm{P}=.03]$ ); Digit Span Test (Forward $[\mathrm{P}=.01]$ and Backward $\mathbb{P}=01])$; and Logical Memory $(\mathrm{P}=.01)$, Visual Reproduction $(\mathrm{P}=.04)$, and Associate Learning $(\mathrm{P}=.03)$ subtests of the Wechsler Memory Scale.

Concussions incurted in soccer were inversely correlated with performances on Digit Span Test (Forward) ( $=.004)$, Facial Recognition Task ( $=.001$ ), Complex Figure Test (Immediate Recall) ( $\mathrm{P}=.04)$, Complex Figure Test (Delayed Recall) $(\mathrm{P}=03$ ), Digit Symbol Modalities Test $(\mathrm{P}=.03)$, and Logical Memory subtest of the Wechsler Memory Scale $(\mathrm{P}=000)$. 
Tabe 2 Psychometric performance of controls and amateur socen players".

\begin{tabular}{|c|c|c|c|}
\hline Neuropsychological test & $\begin{array}{l}\text { Mingn } \\
\text { controls }\end{array}$ & $\begin{array}{l}\text { Wana socert" } \\
\text { playery }\end{array}$ & $\begin{array}{l}\text { Adjusted differene } \\
\text { (95\% (a) }\end{array}$ \\
\hline \multicolumn{4}{|l|}{ Dlanning 0 ss-1es: $P=.001$} \\
\hline Wisconsin Card Sortin Task & & & \\
\hline number of persevetations & 4.26 & 609 & $3.35-1.0410$ \\
\hline number of shits & 4.61 & $3.76^{2}$ & $4.51-1.67$ 100 \\
\hline Compliex Tigure Test copy & 35.30 & $34.61^{\prime}$ & $-0.57-1.50$ \\
\hline
\end{tabular}

Mental Speed OLS-test: $P=0.08$

Bourdon- Wiersma test:

Number of seconds
MASAT

$\begin{array}{rr}602.12 & 617.61 \\ 3.68 & 5.67\end{array}$

$17.98-41.2$ to 772
$214-1.61$

Artention ols-test: $P=10$

Bourdon-Wiersma rest:

Numbet of mistakes

Stroop 1

$\begin{array}{rr}6.00 & 5.03 \\ 39.64 & 37.91 \\ 51.40 & 50.30 \\ 77.76 & 82.24 \\ 20.85 & 19.52 \\ 49.68 & 40.45 \\ 68.47 & 69.42 \\ 5.38 & 5.00 \\ 6.50 & 5.70\end{array}$

$-1.63 \cdot 5.19$ to

1.92

Stroop II

3.91

$-1.65-5.38$ to 208

Sitoop III

2.24

Trahl-rmaking $A$

9.52

Trablumaking $B$

40.45

Digit Symbol Modalitus Tes:

69.42

Digits Backwards

5.00

$-0.18-408$ to 3.73

Digits Forward

650

$4.09-4.82$ to 13.00

$-2.14-6.34$ to 2.06

$-11.52-19.39$ to -3.65

$-4,02-13.98$ to 5.93

$-0.72^{\prime}=1.34$ to 0.11

$.0 .68-1.28$ to 0.08

Memory OLS-test: $P=004$

Complex Fugare Test STM

26.37

23.58

$-3.52^{\circ}-7.18$ to

0.13

Complex Figure Test LTM

24.93

22.82

$-2.56-5.76$ to

0.64

Wechster Memory Scalle

Associate llearning

27.48

26.38

$-2.14^{6}-4.43$ to

0.15

Logical Mernory

19.04

16.64

Visual Reproduction

11.00

$10.00^{\prime \prime}$

15-Word Learning "Test

51.46

53.67

$-2.80^{\circ}-6.08$ to 0.49

$-0.92^{\circ}-1.96$ io 0.18

$0.07=7.61 \% 7.75$

Abstract Reasoning Situdent st thest: $P=48$

Maven Progressive Matrices

$53.56 \quad 54.09$

$0.21-2.82$ to 2.40

Fine Motor Behavior ons-test: $P=0$.

Punchure Test nondominane hand

$75.26 \quad 82.61$

$5.07-1.43$ to 11.56

Puncurte Test dominath hand

93,26

96.49

$0.36-3.18$ to 3.89

Viswa Perceptional Skills otstest $P=22$

Bentan Iacial Recognion Tesn

22.96

22.73

$-0,98 \quad-235$ to $\quad 0.36$

Figune Detection test

16,86

16.03

$.0 .90-2.23$ m 0.43

Verbal Fluency oLSfest: $p=19$

Verbal Muchey Test animals

$29.11 \quad 30,23$

$2.43-1.27$ to 6.12

Verbal Fluency Test, protessions

21.26

22.90

$0.60-3.16$ to 4.35

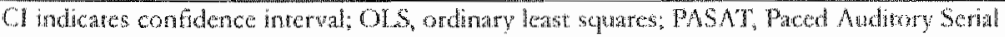

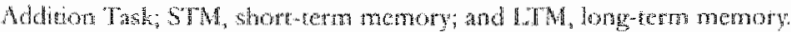

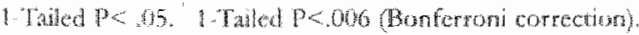




\section{Comment}

These findings suggests that participation in amateur soccer may be associated with mild CTBI, as evidenced by impaiment in cognicive functioning based on tests of memory and planning. Concussions incurred in amateur soccer may play a fundamental role in the development of cognitive impairment observed in these players.

As reported in our previous study of professional soccer players (11), amateur soccer appears to be associated with impairments in planning and memory functions. The Complex Figure Test immediate recall (memory) and the Wisconsin Card Sorting Task (planning) were sensitive in detecting symptoms of neurocognitive impairment in amateur soccer players. According to standards used in clinical practice (27), $7 \%$ of controls and $27 \%$ of amateur soccer players showed mocterately to severely impaired scores on the memory test and $13 \%$ of controls and $39 \%$ of amateur soccer players showed moderately to severelly impaired scores on the planning test. The neurological effects of amateur soccer appear to be related to soccer-related concussions caused by contact trauma. Most of the memory tests that showed a significant difference between the soccer players and the controls were inversely related with concussions incurred in soccer in the intragroup analysis.

In conclusion, participation in amateur soccer is associated with decteased performance on tests of memory and planning. Although the cognitive impaitment appears to be mild, it presents a medical and public health concern, with 200 million Federation International Football Association-registered soccer players worldwide. Methods for suveillance and prevention should be developed and adopted to maximize salety. 


\section{References}

\section{Chapter 4}

1. Critchley M. Medical aspects of boxing; particulaly from ancurological standpoint. British Medical Journal $1957 ; 1: 357-362$.

2. Robberts AH. Brain Damage in Boxers, London: Pittman Medical and Scientige Publishers Compary LTD, 1969.

3. Jordan BD. Neurologic Aspects of Boxing Archives of Neurology 1987; 44: 453-459.

4. Mendez MF. The neuropsychiatric aspects of boxing: Intemational Journal of Psychiatry in Medicine 1995; 25: 249-62.

5. Matser JT. Sponzen en aspitines, voldoende bij hoofdletsels in sport?. Geneeskunde en Sport $1996 ; 29: 66-73$.

6. Corsellis JA. Brain damage in sport. Lancer 1976; 1.401-402.

7. Tysvaer AT, Lochen EA. Socrer injuries to the brain. A neuropsychological study of formet soccer players. The American Jownal of Sports Medicine 1991; 19: 56-60.

8. Sortiand O Tyswaer A.T. Brain damage in former association football players, An evaluation by cerebral computed tomography. Neurondiology 1989; $31: 44,489$

9. Tyswaer AT, Storli O, Bachen NI. Socer injurtes to the brain. A neurologic and dectrocneephalographic study of tormer players. Acta Neurologiea Scandinavica 1989b; 80: 151-150.

10. Tyswaer AT, Stomli, O. Association Football Injuries to the Brain, A Preliminary Report. Butish Journal of Sports Medicine 1981; 15: 163-166.

11. Matser JT, Kessels AGH, Jordan BD, Lezak MD, Troost J. Chronic Traumatic Brain Injury in Professional Soccer Players. Neurology 1998;51:791-796.

12. Jordan $S E$, Green GA, Galanty H. Mendelbaum BR, Jabour A. Acute and Chronic Brain Injury in United States National Team Soccer Players. The American Joumal of Sports Medicine 1996; 24: $205-210$.

13. Witol A, Webbe F. (1994). Neuropsychological Deficits Associated with Soccer Play. Archives of Clinical Neuropsychology 1994; $9: 104$.

14. Raven JC. Guide to the Standard Progressiwe Mattices London: HK Lewis, 1960.

15. Betg EA. A simple objective treatment for measuring thexibility in Thinking Journal of Gemeral Psychology 1948; 39: 15-22.

16. Gronwall DMA. Paced Auditory Serial Adclition Task: A measure of recovery from concussion. Perceptual and Motor $\$$ kills $1977 ; 44: 367-373$.

17. Wechster D. WAIS-R Manual. New York: The Psychological Corporation 1981.

18. Army Indiwidual Test Batery, Mamal of Directions and scoring Washington DC: War Deparment Adjuant General's Offec, 1944.

19. Golden Cf. Strop Color and Word Test> Chicago, IL: \$twelling, 1978.

20. Van de Loo l.. Enkele beschouwingen ower de Bourdon. Wiersma test. Tijdschrift wan de psychologische kring van de Nijmeegse Universiteit 1956; 2:33-46.

21 Wechsler D Wechsler Memory Scale manuat. San Antonio, "T X: "The Psychological Componation, 197.

22. Osterieth PA Le test de copie d'une tigure complexe. Archives de Psychologic 1944, 30, 206356.

23. Deelman $B G$, Browwer WH, van Zomeren A.H. et al. Functiestoomissen na rama capitis. Ir: Jennekens-Schinkel A, et al, Eds. Nexropsychologie in Nederland. Deventen: Van Loghum Staterus, 1980. 
24. Berton AI, Hamsher $K$, Varny $N$, Spreen $O$. Contriburions to newropsyehological assessment. New York: Oxford Uniwersity Press, 1983.

25. Liteyn E Een nieuwe verkorte GIT. Dutch Journal of Psychology 1966; 2* 675-652.

26. Van der Whgt H Lateralisatses wan hersenfuncties: een neuropsychologiseli onderzoek naar de relatite tuster handwoorkeur en de relatie wan de talfifunctie. Dissertatie, Lisse, Swets \& Zeithinger, 1979 .

27. Lezak MD Netropsychological Assessment 3nd ed. New York: Oxford University Press, 1995

28. OBrien PC. Drocedures for comparing samples with multiplle endpoints. Biometrics 1984 ; 40: $1079-1087$.

29. Later $]$. Exact $\mathrm{T}$ and $\mathrm{F}$ tests for analyzing studies with nultiple endpoints. Biometrics 1996 ; 52. 964.970 .

30. Kelly JP; $\mathbb{R}$ osenlberg JH. Dingnosis and manament of concussion in sports. Neurology 1997; 48: $575-580$ 
Chapter 5

\section{Chronic traumatic brain injury in professional soccer players*}

JT Matser MSc (1), AGH Kessels, MD (2), BD Jordan MD (3), MD Lezak PhD (4), JTroost MD (5).

1. Department of Neuropsychology and Sportsneurology, St. Anna Hospital Geldrop, The Nethetlands

2. Department of Epidemiology, University of Maastricht, The Netherlands

3. Department of Neurology $y_{*}$ UCLA School of Medicine, Los Angeles, USA. Biobehavorial Research Center, Charles R Drew University of Medicine \& Science, Los Angeles, USA

4. Department of Neurology, Oregon Health Sciences University Pottland, USA

5. Department of Neurology, University Hospital of Maastricht, The Netherlands 


\section{Abstract}

Objective: To determine the presence of chronic traumatic brain injury in professional soccer players.

Methods: Fifty-three active professional soccer piayers from several professional Dutch soccer clubs were compared with a control group of 27 elite noncontact sport athletes. All participants underwent neuropsychological examination. The main outcome measures were neuropsychological tests proven to be sensitive to cognitive changes incurred in contact and collision sports.

Results: The professional soccer players exhibited impaired performances in memory, planning, and visuoperceptual processing when compared with control subjects. Among professional soccer players, performance on memory, planning, and visuoperceptual tasks were inwersely related to the number of concussions incurred in soccer and the frequency of "heading" the ball. Performance on neuropsychological testing also varied according to field position, with forward and defensive players exhibiting more impairment.

Conchusion: Participation in professional soccer may affect adversely some aspects of cognitive functioning (i.e., memory, planning and visuoperceptual processing).

Key words: Soccer - Chronic Traumatic Brain Injury - Cognitive Impairment Heading

\section{Introduction}

Worldwide, soccer is the most popular and frequently played sport with at least 200 million registered participants (1). Although soccer is considered safe by the general public, the American Academy of Pediatrics has classified saccer as a contact/collision sport (2). Accordingly, acute traumatic brain injury (ATBI) is a concern in soccer. It is notable that the concussion rates per 1,000 athlete exposures in American football and men's soccer are equal (3). Furthermore, fatal neurologic injuries in soccer have also been reported. During the period from 1931 to 1974, 26 English soccer players experienced faral traumatic brain injuries, including 8 attributed to "heading" the ball (4). In the United States, from 1979 to 1993, 18 fatal accidents were reported from players running into goalposts (5). Another four fatal 
accidents in high school soccer have also been documented between 1980 and 1988 (6).

In addition to ATBI, chronic traumatic brain injury (CTBD) is of concern in soccer. CTBI, which represents the longuterm cumulative neutological consequence of concussive and subconcussive blows to the head, has been described primarily among professional boxers (7-10). However, it has been speculated that CIBI can occur in soccer (11). In a survey of British neurologists, a traumatic encephaloparhy resembling that encountered in boxing has been reported in soccer players (12). Tyswer and Lochen (13), Sortland and Tyswaer (14), and others have obserwed neuropsychological impairment (13), CT pathology (14), and EEG abnormalities (15) among retired soccer players in Norway. In contrast, a more recent investigation (16) of active soccer players on the United States national team failed to demonstrate any significant neurological symptomatology (MRI) when compared with control subjects. There are two distinct mechanisms by which CTBI can occur in soccer. First, because the cognitive impairment from concussion can be cumulative (17), CTBI can occur from repeated, relatively mild concussions, In soccer, concussions may occur from typical contact sport collisions: head-to-head, head-togoalpost/ground, and head-to-body (e.g, elbow, foot, knee) collisions. However, unlike some other contact sports (e.g, American football), soccer players do not wear protective headgear.

The second mechanism for potential CTBI is a discinguishing feature of soccer: repetitive heading of the ball. It has been estimated that professional soccer players play approximately 300 division games and head the ball more than 2,000 times during their career (18). This is compounded by the fact that a plastic-coated soccer ball weighs 396 to $453 \mathrm{~g}$, and the speed of the ball can reach 60 to $120 \mathrm{~km} / \mathrm{h}(19)$. It has been calculated that a ball kicked with half power from a distance of $10 \mathrm{~m}$ travels $83.2 \mathrm{~km} / \mathrm{h}$ and hits the head with an impact of $116 \mathrm{kPa}$. Kicked with full power the ball hits the head with $200 \mathrm{kPa}$ (20). Together these mechanisms suggest that soecer players are particularly vulnerable to head injuries with consequent CTBI.

The current investigation tested the hypothesis that CTBI is associated with professional soccer as evidenced by impairment on neuropsychological testing. This study also sought to identify possible risk factors for CTBI (c.g, soccerurdated concussions, heading the soccer bally and to evaluate their contributions to neurocognitive dys function in soccer players. 
soccer-related concussions, heading the soccer ball) and to evaluate their contributions to neurocognitive dysfunction in soccer players.

\section{Methods}

\section{Subjects}

The volunter group of this investigation consisted of 53 active Dutch male professional soccer team members and 27 male control subjects. The control subjects were members of elite swimming and track teams in the Netherlands. All participants in this study were interviewed and examined using an extensive neuropsychological test battery. Soccer players and control subjects participated in an extensive interview that incuired about age, education, number of general anaesthesias, occupational history, number of concussions (sports and nonsports related) in a lifetime, alcohol intake, drug use and medical conditions that might affect cognitive functioning (table 1). Education was scored on a seven-point scale and, because all participants completed their secundary school education, only the levels 3 (technical and vocational training for 12-to 16-year-olds) to 7 (academic level) were used. In addition, the team physicians of the professional soccer players were interviewed concerning the number of concussions (sports and nonsports related) and medical conditions that might interfere with cognitive functioning. All the particlpants in this study were native Dutchmen who were educated in the Dutch educational system. Nonnative Dutchmen and people who were not cducated in the Dutch school system wete excluded. Other exclusion criteria included history of drug abuse, epilepsy, and medical conditions that might affect cognitive functioning.

Table 1 Characteristics of soccer players and controls, and p-values.

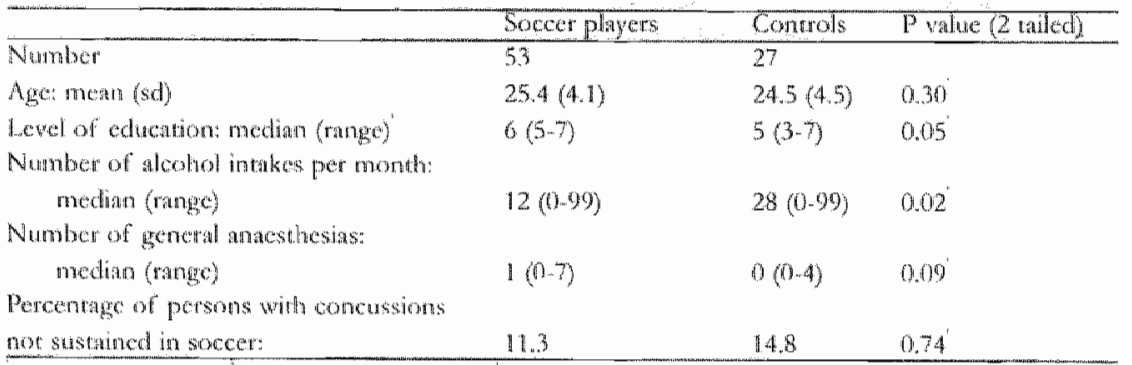

Student's r-test. Mann-Whimey $U$ rear. Fishers exact test.

Eduction levels ate scored on a $3,3=$ qechnol and wocational maing for 12 to 16 years old in 7 o madenic levely scalc. 
Group comparisons were made berween professional soccer players and control subjects for level of cognitive functioning. Intergroup comparisons were made in soccer players who do many "headers" and these who do not (non-headers). Midfield players and goalkeepers were classified as nonheaders, and forward and defensive players were classiffed as headers. Trauma index variables regarding the number of concussions with or without loss of consciousness (soccer related), duration of professional soccer careet, the number of headers produced each match, and the number of matches in one season were also determined for the professional soccer players. By multiplying the number of headers each match with the number of matches, we estimated the total number of headers in one season.

\section{Neuropsychological testing}

In the current investigation, neuropsychological tests that have proven to be sensitive in the detection of cognitive impairment in contact and collision sports 13 , 21-23) were used. Each participant in this study received a battery of neuropsychological tests that were administered by a trained psychometrician. The interview was performed by a qualified neuropsychologist. All tests were administered according to standardized instructions and procedures. The test data were scored by a qualified neuropsychologist who was blinded to the status (professional soccer player or control subject) of the participant. "The neuropsychological test battery included the following: Raven Progressive Matrices Test (RPM) (24), Wisconsin Card Sorting Task (WCST) (25), Paced Auditory Serial Addition Task (PASAT; slowest version) (26), Digit Symbol'Test (27), Trail Making A and B (28), Stroop test (29), Bourdon-Wiersma Test (30), subtests of the Wechsler Memory Scale (WMS; Associate Learning, Logical Memory, and Visual Reproduction (31), Complex Figure Test (Copy, Immediate Recall, and Delayed Recall) (32), 15-Word Learning Test (33), Benton's Facial Recognition Task (34), Figure Detection Test (35), Verbal Fluency Test (35) and the Puncture Test (36).

\section{Statistical analysis}

Comparisons of the neuropsychological test scores were performed by calculating the differences between the means using the Student's t-test. With a linear regression analysis these differences, their CIs, and one-tailed $p$ values were determined, adjusting for the level of education, alcohol intake, number of general anesthesias, and number of concussions not sustained in soccer. To determine the association between heading-related variables and test scores, unadjusted and adjusted regression coefficients and their $\mathrm{p}$ values were calculated using a univariate and a multivariate linear regression model, respectively. 
Because 27 outcome variables are compared, we performed a Bonferroni correction on the significance level. Furthermote, using the ordinary least squares (OLS) test as described by $O^{\prime}$ Brien (37) and modified by Lauter (38), we tested a global null hypothesis.

\section{Results}

\section{Population characteristics}

Chatacteristics of the study population are presented in table 1 . The average age of the soccer players was $24.4 \pm 4.1$ (SD) years compared to $24.5 \pm 4.5$ years in the control group $(\mathrm{p}=0.3)$. There was no significant difference between the percentage of people sustaining concussions unrelated to soccer (11.3\% in the professionals and $1.4 .8 \%$ in the control subjects, $p=0.7$ ). None of the professional soccer players in this study abused drugs. Higher alcohol consumption was noted in the control subjects $(p=0.02)$. Soccer players achieved a higher educational level $(p=0.05)$ and experienced a greater number of general anesthesias $(p=0.09)$. Among the 53 professional soccer players, $54 \%$ experienced one or more socer associated concussions with or without loss of consciousness. During their professional carcers $79 \%$ of the players sustained one or more head-to-head collisions (with or without post concussive symptoms).

Professional soccer players teported a median of 800 (range, 50 to 2,100) headers during competitive matches in one soccer season. Headers experienced in training sessions wete excluded from this approximation. The median of the number of headers during a match was 16 (range, 1 to 42 ). Approximately, $47 \%$ of the players headed the ball 0 to 10 times, $36 \%$ headed the ball 11 to 20 times and $17 \%$ headed the ball 21 or more times during an average match. Thirty percent of the players also participated in heading drills during training. These drills consisted of repetitive heading of the ball for 30 minutes once a week.

The median of the number of soccer matches played annually was 50 (range, 25 to 70 ), and the median of the number of practices per week was six (range, 4 to 9). Ninety-two percent practiced 4 to 7 times a week and $7.5 \%$ practiced more than seven times a week. An average training session lasted 2 hours. 'Twenty-four percent of the players in this study were forward players, $45 \%$ were midfield players, and $30 \%$ were defense players.

Soccer players experienced extensive amater and professional carcers. The median of an amateur soccer career was 12 years (range, 4 to 23 years). Thirty percent of the players played 4 to 10 years, $57 \%$ played 10 to 16 years and $13 \%$ played 16 years or 
longer as amateurs. The median of the duration of a professional soccer cateer in this study was 5 years (tange, 1 to 18 years). Professionally, $43 \%$ of the players participated 1 to 5 years, $30 \%$ played 6 to 12 years and $27 \%$ played more than 12 years.

\section{Neuropsychological testing}

We examined the distributions of the test scores on outliers and skewness. "The skew of the distributions necessitated a log transformation for six scores-namely, the Bourdon-Wiersma test (number of mistakes), the PASAT, Facial Recognition Test, the Complex Figure test (Copy), the Puncture test (dominant hand), and the total Raven score - to symmetrize and normalize the distribution. The analysis was done with these transformed scores, but in the following the inversely transformed values are presented.

Table 2 shows that professional soccer players exhibited more cognitive impairments when compared to control subjects. Professional soccer players performed poorer on verbal and visual memory, planning, and visuoperceptual processing tasks compared to control subjects. On a number of tests, the differences between the two groups (i.e., Figure Detection Groninger Intelligence "Test [GIT] subtest, The Complex Figure Test [Copy, Immediate, and Delayed recall], Logical Memory [WMS], and Visual Reptoduction [WMS], remained significant after adjustments for confounding variables the number of concussions not related to soccer, alcohol consumption, level of education and the number of gencral anesthesias). These psychometric test scores also remained significant after a Bonferroni correction. Furthermore, the one-tailed $p$ value based on the OLS test statistic was $0.00006\left(Z_{a,}=3.84\right)$. Evidence for a dose-reponse relation between selected soccer-related exposure variables and the neuropsychological test scores was demonstrated (Table 3). An increasing number of headers and concussions incurred during soccer participation were associated negatively with memory, visuoperceptual, and planning capacity. The number of headers was inversely associated with test scores on Complex Figure Test Immediate $(\rho=0.048)$ and Delayed Recall score $(\mathrm{p}=0.01)$. The number of concussions sustained in soccer was inversely associated with the test score on the Complex Figure 'Test Copy $(p=0.01)$. Field position also influenced performance on neuropsychological testing. Forward and detensive players performed significantly poorer on Figure Detection $(\mathrm{p}=0.01)$, Complex Figure Test Immediate $(p<0.001)$, Delayed Recall $(p<0.001)$, Logical Memory (WMS, $p=0.02$ ), and Visual Reproduction (WMS, $p=0.02$ ) compared with midfield players and goalkeepers. 
Thble 2 Comparison of psychometric performance between contral subjects and professional soccer players.

\begin{tabular}{|c|c|c|c|c|}
\hline Tegit & $\begin{array}{l}\text { Mean } \\
\text { contribls } \\
\text { scones }\end{array}$ & $\begin{array}{l}\text { Unadjusted dife } \\
\text { rence (1-tailed } \\
\text { pualue) }\end{array}$ & $\begin{array}{l}\text { Adjusted dife } \\
\text { rence (1-tailled } \\
\text { pualue) }\end{array}$ & $99.63 \% \mathrm{Cl}$ \\
\hline \multicolumn{5}{|l|}{ Parti 1} \\
\hline Bourdon wiotsma test & & & & \\
\hline Number of mistakes & 6.10 & $2.20(0.03)$ & 1.47 & -1.65 to $\quad 7.12$ \\
\hline Number of seconds & 602.12 & 5.77 & .9 .79 & -88.2 no 68.4 \\
\hline$P A B A$ & 3.68 & 106 & 1.38 & -1.62 to 5.19 \\
\hline Srroopl] & 39.64 & -1.07 & -1.59 & -580 to 2.64 \\
\hline stroop 11 & 51.40 & .0 .74 & -1.71 & -7.72 to 4.30 \\
\hline Stroop III & 77.76 & 1.41 & 2.86 & .6 .82 to 12.54 \\
\hline Trailmaking A & 20.85 & 1.46 & 1.33 & -4.02 to $\quad 6.68$ \\
\hline "Trailmaking $B$ & 49,68 & 1.38 & 0.03 & $-12,14$ to 12.08 \\
\hline Wisconsin: number of persewerations & 4.26 & $3.63(<0.001)$ & $3.93(0.002)$ & $-0.12,0 \quad 7.98$ \\
\hline \multicolumn{5}{|l|}{ Part II } \\
\hline Wisconsin number of shifts & 4,61 & $-0.68(0.026)$ & $-0.69(0.04)$ & -1.88 to $\quad 0.50$ \\
\hline Digits Batckwords & 5.38 & -0.21 & -0.48 & -1.34 to 0.40 \\
\hline Digits Forward & 650 & -0.41 & $-0.52(0.03)$ & -1.36 to -0.32 \\
\hline Facial Recognition Test & 22.96 & 0.10 & -0.28 & -2.44 to 1.15 \\
\hline Eigure Detection & 16.46 & $-3.34(<0.001)$ & $-3.66(<0.001)$ & $-6.14+10 \cdot 1.18$ \\
\hline Complex I'igure Test Copy & 35.30 & $-1.73(<0.001)$ & $-1.25(c 0.001)$ & -2.45 to -0.48 \\
\hline Complex Figure Hest $5 \mathrm{TM}$ & 26.37 & $-8.09(<0.001)$ & $-7.55(<0.001)$ & -12.32 to -2.80 \\
\hline Complex Figure Test LTM & 24,93 & $-7.15(<0.001)$ & $-5.87(<0.001)$ & -9.94 too -1.80 \\
\hline Fuency, anmals & 29.11 & -0.11 & -0.69 & .594004 .56 \\
\hline Fluency, professions & 21.26 & -0.52 & -11.20 & -5.46 to 3.76 \\
\hline Puncture Test nondominant hand & 75.26 & .090 & 1.29 & -7.80 to 10.38 \\
\hline Pencente Thet dominant hatid & 53.26 & .0 .23 & .0 .41 & .796 wo 5.42 \\
\hline Towal kinen score & 53.50 & $-1.99(0.03)$ & $-2.31(0.003)$ & -6.15 to 0.12 \\
\hline Degent Symbol & 68.47 & -3.81 & -5.08 & $-15.9210 \quad 5.88$ \\
\hline Associate Learnugh & 27.48 & $-1.32(0.01)$ & $-1.49(0.01)$ & -3.3400 .30 \\
\hline 1.ogical Mentory & $19) .94$ & $-4.38(<0.001)$ & $-460(40.001)$ & $.8 .6060-0.60$ \\
\hline Viswa Reproduction & 11.00 & $-1.89(<0.001)$ & $-202(<0.001)$ & -3.50 ro -0.52 \\
\hline 15 word loming Test & 51.40 & -2.22 & 2.95 & $-9.66 \mathrm{co} \quad 3.6$ \\
\hline
\end{tabular}

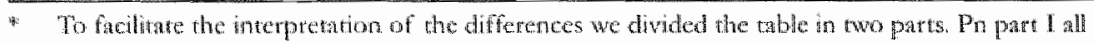
test sores are inchded that are correlated positwely with cognitiwe impaiment. In part II all fest scores ate cortalad negatively.

+ Controls are dite switzmets and clite 800-meter wanners.

In accordance with the Bonferoni correction.

PASAT = Paced Auditory Serial Additon Tists STM = short term memory;

ITW $=$ long term menory. 
Table 3. Associations between heading-related variables and test scores in the group of soccer players.

\begin{tabular}{|c|c|c|}
\hline & $\begin{array}{l}\text { Unadiusted seore } \\
\text { pwatuc) }\end{array}$ & $\begin{array}{l}\text { Adjusted score } \\
\text { (p value }\end{array}$ \\
\hline \multicolumn{3}{|c|}{ Field position, headers v's non-lineaders } \\
\hline Tigure Detecrion & $-1.84(0.02)$ & $-209(0.01)$ \\
\hline Complex Figure "Test copy & $-1.25(0.01)$ & $-1.30(0.01)$ \\
\hline Complex Figure Tesr STM & $-6.34(00001)$ & $-6,08(<0,00 t)$ \\
\hline Complex Figure Tose LTM & $-5.36(<0.001)$ & $-5.17(<0001)$ \\
\hline Logicall Menory & $2.88(0.02)$ & $-302(0.02)$ \\
\hline Visual Reproduction & $-1.24(0.01)$ & $.1 .19(0.02)$ \\
\hline \multicolumn{3}{|c|}{ Namber of concussions in a liferime } \\
\hline Complex Figure Test copy & $-0.20(0.03)$ & $-0.25(0.02)$ \\
\hline \multicolumn{3}{|c|}{ Numbet of headers in one season } \\
\hline Complex Figure Test STM & $-0.16(0.048)$ & $-6.17(0.048)$ \\
\hline Complex Figure Test ITVH & $.0 .20(0.008)$ & $0.19(0.01)$ \\
\hline
\end{tabular}

Adjusted and unadiputed segression coefficients and their $p$ watues are shown for the associations

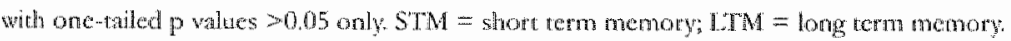

\section{Discussion}

These findings suggest that professional soccer may be associated with neurocognitive impairment. The observed impaiment in neuropsychological function preferentially involves memory, planning and visuoperceptual processing. Forward and defensive players tend to be more valnerable to cognitive impaiment because they are more likely to head the ball and experience a higher frequency of soccer-related concussions. Our findings are in agreement with those of Tysvaer and Lochen (13), who showed a higher degree of neuropsychological imparment in headers than in nonheaders ( $20 \%$ versus $8 \%$ ), In their study, $73 \%$ of the former professional soccer players showed neurocognitive impaiment $3 \%$ severe, $38 \%$ moderate, and $32 \%$ mild). The neuropsychological differences between the retired players and the control subjects were documented in tasks regarding petception, learning, and mental speed. The players in the study of Tyswaer and Lochen (13) had an average age of 48.6 years (range, 35 to 64 years) and were retired.

In a neurological cvaluation of 20 soccer players on the United States national team (16), no association was found berween heading the soccer ball and neurological 
symptoms, including MRI-detected abnormalities. The discrepancy between this investigation and out findings may be related to methodological issues. This study did not use the more sensitive neuropsychological techniques nor did it distinguish between different styles of soccer play in training and competition.

The Complex. Figure Test proved to be sensitive to detecting symptoms of neurocognitive impaiment in professional soccer players. The sensitivity of the Complex Figure Test may be explained by the fact that this test requires memory, planning, and visuo-spatial ability (i.e., cognitive functions that are sensitive to deterioration after concussion and multiple trivial impacts). According to the standard of Osterieth (32), as used in clinical practice, $7 \%$ of the control subjects and $45 \%$ of the professional soccer players showed moderate to severe impaired scores. Surprisingly, the PASAT Test did not differentiate between soccer players and control subjects. In this study we utilized the slowest PASAT version, which could explain the lack of sensitivity.

In our cross-sectional study, several methodologic precautions were taken to minimize the problems associated with group comparisons. All the participants in this study were native Dutchmen who were educated according to the Dutch educational system, therefore eliminating misinterpretations caused by educational differences. In addition, dirug users and participants with medical condirions that might interfere with cognitive functioning were excluded from this investigation.

Other potential biases associated with physical exertion and exercise in soccer were excluded by using elite swimmers and runners as control subjects. "To ensure reliability, tests and interviews were administered by a certified neuropsychologist and trained psychometricians. The test scores were scored by a neuropsychologist who was not informed about the status (professional soccer player or control subject) of the participants. Confounding variables such as alcohol use, the number of concussions not sustained in soccer, the level of education, and the number of gencral anesthesias were adjusted by using multivariate regression analysis. The problem with multiple end point testing was controlled by a Bonfertoni correction of the significance level and a global null hypothesis testing procedure.

Difference in mentality and test attitude could also explain these results. However, soccer players had a higher level of education, and all participants were tested by a trained psychometrician. Nevertheless, there may be inherent differences between those who choose to play soccer and those who choose to swim or run that may affect neuropsychological test performance and that may not be captured adequately in the variables we controlled. Our findings that ptofessional soccer is associated with neuropsychological impairment supports the hypothesis that CTBI is a health 
problem for soccer players. Although the nenropsychological impairment is milder than what might be anticipated in boxing, the dose-reponse relation between traumatic brain injury (i.e, concussions and heading the ball) and cognitive impairment presents a medical and public health concern. Accordinghy, surveillance and prevention measures should be undertaken to maximize safety. For example, soccer players should have a medical exaluation after sustaining a concussion. Baseline neuropsychological testing (performed in preseason) and postconcussion sideline follow-up evaluations may be useful in determining the effects of concussion and the appropriateness for return to competition. To limit the adverse effects of heading the ball, precautionary measures need also be established. In other contact sports with similar concussion rates (e.g., American Football (3)), these preventive measures are tecommended.

Participation in professional soccer may affect adversely some aspects of cognitive functioning (i.e., memory, planning, and visuoperceptual processing). This impairment in neurocognitive function appears to be attributed to increased heading of the ball and soccer-related concussions experienced by forward and defensive players. Whether our findings can be extrapolated to amateur or lower exposure soccer players remains to be determinated in future investigations.

\section{Acknowledgments}

We thank H.J.A. Schouten PhD for his helpful statistical advices.

\section{References}

Chapter 5

1. Statistics on the 150 affilinted National Associations of Fifa. Fifa News 1982; 235:538.

2. American Academy of Pertatrics Policy Statenent Recommendenons for participation in competive sports. The Ibysician and Sprotemedicine $1988 ; 16: 165-167$.

3. Kelly Jip , Rosenberg JH. Diagnesis and management of concussion in sports. Nevalogy 1997 48: $5,5-580$.

4. Hughes $\mathbb{R}$ Head damage. A waming to all payers. The Sumay 'Times, nov 10, $0 \% 4$.

5. DeMarco J, Reeves, C. Injutes assonited with socer goalposts, Unted Statcs, 1979-19003. IANA 1994; $271: 1233$.

6. Mueller FO, Cantu $\mathbb{R C}$. Catastrophic injuries and tatalites in high school and college sports, 1982 1988. Medicine and Science in Sports and Exencise 1990, 22: 737.741.

7. Critchley M. Medical aspects of boxing particulaty from a menological statipont. Btish Medical Journal $1957: 1: 35,-362$.

5. Robberts AH. Bran Domage in Bomers. London: Pitman Medical and Sciontic Publishers Company LiT), $196 \%$. 


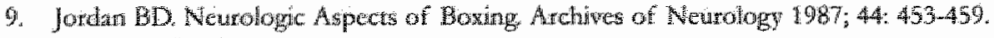

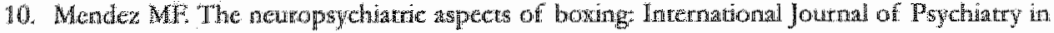
Methine $1995 ; 25: 249-262$

11. Matser J $\mathrm{r}$ sponzen en aspirines, woldoende bij hoofdletsels in sport? Geneeskande en Sport $190 \% 6 \% 29: 66 \times 73$

12. Corgellis JA. Brain dariage in sport. Lancet 1976; 1: 401-402.

13. Tyswer $A T$, Lochen $B A$. Socect injuries to the brain A neuropsychological study of former socer players The American Journal of Sports Medicine 1991; 19.56-60.

14. Sortand $O$, Tyswaer AT. Brain damage in former association football players. An exaluation by cerebral computed tomography. Neuroradiology 1989; 31: 4448

15. Tyswat AT, Storli $O$, Bachen NI. Soccer injuries to the brain. A neurologic and electro encephalographic study of fomer players. Acta Neurologica Scandinaviat $19896 ; 80: 151-156$.

16. Jordan SE, Green GA, Galanty H., Mendelbaum BR, Jabour A. Acute and Chronie Brain Injury in United States National Team Soceer Players. The American Journal of Sports Medicine 1996; 24: $205-210$.

17. Gronwall DMA, Wrightson P. Cumulative effect of concussion. Lancet $1975 ; 2: 995-997$.

18. Tysvaer Ar, Storli, O. Association Football. Injuries to the Brain A Preliminary Report. British fowrmal of Sports Medicine 1981; 15: 16.3-166.

19. Keller D, Hennemann MC, Allegrai \. Fussball, der Lifneter. Leistungsport 1979; 9; 394.398.

20. Von Schneider PG, Lichte H. Untersuchungen zur Gröse der Krafteinwirkung beim Koplballspiel des Fussballers. Sportiarcz und Sportmedizin 1975; 26: 222-223.

21. Witol A, Webbe F. Neuropsychological Deficiss Associated with Soccer Play. Archives of Cinical Nouropsychology 1994; 9: 104.

22. Matser J"T, de Bijl MAO, Luijtelaar ELJ. Is amateur boxing dangerous? De Psycholoog 1992 ; 12: $515-521$.

23. Jortlan BD, Matser JT, Zazula T. Sparring and cognitive function in professional boxers. The Plysician and Sportsmedicime 1096; 24:87-98.

24. Rawen JC. Guide to the Standard Progressiwe Matrices. London: HK Lewis, 1960.

25. Berg $\mathrm{EA}$ A simple objective treament for measuring flexibility in thinking Journal of General Psychology $1948 ; 39: 15-22$.

26. Gronwall DMA. Paced Auditory Serial Addition Task: theasure of recovery from concussion. Merceptual and Motor Skills 1977; 44:367-373.

27. Wedisler D WAIS-R Manual. New York: The Psyehological Corporation, 1981.

28. Spewn O, Strass L. A compendium of neuropsychological tests. New York: Oxford Universtry Prcisis, 1991.

29. Golden Cy. Stroop Coloe and Word Test. Chicago: Stoelling 1978.

30. Van de Loo L. Enkele beschouwingen over de Boudon. Wiersma test. Tijdschift van de psychologische kring wan de Nijnegegre Universiteit $1956 ; 2: 33-46$.

31. Weclisler D. Wechsler Memony Scale Manual. San Antonio: "The Psychological Corporation, 1974.

32. Osterieth PA Le test ac copie d'une figute complexe. Archives de Psychologie 1944, 30: 206356.

33. Decman BG, Brouwer WH, van Zomeren AH. Functiestoornissen na trauma capitis. In: Jennekens-Schinkel $A_{x}$ at at, eds. Neuropsychologe in Nedethand. Deventer: Van Loghum, Slaterus, 1980. 
3. Benton $\mathrm{AL}_{\mathrm{s}}$. Hansher $\mathrm{K}$, Varney $\mathrm{NR}$, Spreen $\mathrm{O}$. Contributions to netropsychological assessment. New York: Oxford Uniwersity Press, 1083.

35. Luteyn E. Een nieuwe werkotte GIT. Dutch Joumal of Psychology 1966; 2:675 682

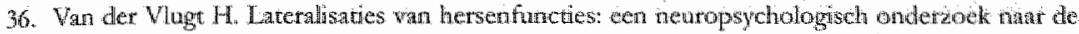
relate tussen handwoorkeur en de relatie van de talfuncte Lissen Swets \& Zeitlinger, 1979.

37. OBrien PC. Procedures for comparing samples with mulnple endpoints. Bionnetrics 1984 : 40: $1079-1087$.

38. Läuter J Exact $\mathrm{T}$ and $\mathrm{F}$ tests for Analyzing Studies with Mulitiple Endpoints. Biometrics 1996; 52: $964-970$ 
Chapter 6

\section{Contribution of headers and soccer related concussions to cognitive impairment in professional soccer players}

JT Matser PhD (1), AGH Kessels MD (2), MD Lezak PhD (3), J Troost MD (4).

1. Department of Anatomy, Erasmus University Rotterdam, the Netherlands

2. Research Unit Patient Care, University Hospital of Maastricht, the Netherlands

3. Department of Neurology, Oregon Health Sciences University, Portland, OR, USA

4. Department of Neurology, University Hospital of Maastricht, the Netherlands. 


\section{Abstract}

Objective: To determine the effect of headers and soccer related concussions to cognitive impaiment in professional soccer players.

Methods: Eighty-four active professional soccer players from several professional premier league soccer clubs underwent neuropsychological evaluation. The number of headers in one professional season and the number of soccer related concussions was investigated concerning cognitive functioning.

Results: Soccer related concussions were inversely related to results of tests measuring sustained attention, planning (organisation)and visuo-perception. The number of headers in one season was inversely related to results of tests measuring focused attention and visual/verbal memory.

Conchusion: It seems that concussions produce a mote diffuse profile of brain injury whereas headers seems to deteriorate fronto-temporal functions.

\section{Introduction}

Soccer players are valnerable for chronic traumatic brain injury (CTBD) (1-7). There are two main distinct mechanisms by which $\mathrm{CTBI}$ can incur in soccer: concussions and headers (1).

In soccer, concussions may occur from typical contact sport collisions; head-tohead, head-to-goalpost/-ground and head to body (elbow, foot, knee) collisions (810). It is notable that the concussion rates per 1,000 exposures in American football and men's soccer are equal (9). In a recent published prospective study, 59\% of american amateur soccer players sustained one or more concussions during two seasons (11). Most of the concussions resulted from contact with an opponent's head $(28 \%)$ or elbow $(14 \%)$. Dutch studies show a concussion rate of $54 \%$ in professional players and $50 \%$ in amateur soccer players during a soccer career $(1,12)$. The second mechanism for potential CTBI is repetitive beading of the ball, a unique aspect of soccer(13-14). Matser et al (1998) documented a median of 800 headers (range 50-2,100) in professional soccer players in a single season (1).

Although, two previous studies showed neuropsychological impairment in amateur and professional soccer players, it remained unclear whether this impaiment was caused by the number of headers or concussions. This study sought to identify the specific contribution of soccer related concussion and headers to neurocognitive dysfunction in professional soccer players. 


\section{Methods}

\section{Subjects}

The volunter group of this investigation consisted of 84 active Dutch male premier league professional soccer players. All participants in this study were interviewed and examined using an extensive neuropsychological test battery. Soccer players participated in an extensive interview that inquired about age, education, number of general anaesthesias, occupational history, number of concussions (sports and

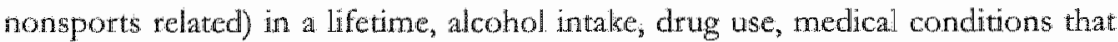
might affect cognitive functioning and the number of headers in the last season (the number of headers in a single match multiplied with the number of matches played in the last season). Education was scored on a sevempoint scale and, because all participants completed their secondary school education, only the levels 3 (technical and vocational training for 12 to 16 year-olds) to 7 (academic level) were used. In addition, the team physicians of the players were interviewed concerning the number of concussions (sports and nonsports related) and medical conditions that might interfere with cognitive functioning. All the participants in this study were native Dutchmen who were educated in the Dutch educational system. Furthermore, soccer players with a history of drug abuse, epilepsy, and medical conditions that might affect cognitive functioning were excluded.

\section{Neuropsychological testing}

In the cur rent investigation neuropsychological tests that have proven to be sensitive in the detection of cognitive impairment due to soccer were used $(1,12)$. Each participant in this study received a battery of neuropsychological tests that were administered by a trained psychometrician. The interview was performed by a qualifien neuropsychologist. All tests were administered according to standardized instructions and procedures. The test data were scored by a qualified neuropsychologist who was blinded to the status of the participants.

The neuropsychological test battery included the following. Raven Progressive Matrices Test (RPM) (15), Wisconsin Card Sorting Task (16), Paced Auditory Serial Addition 'Task (PASAT); slowest version) (17), Digit Symbol Test (18), Trailmaking A and B (19), Stroop test (20), Bourdon-Wiersma Test (21), subtests of the Wechsler Memory Scale (WMS; Associate Learning (all scores added), Logical Memory, and Visual Reproduction) (22), Complex Figure Test (Copy, Inmediate Recall, and Delayed Recall) (23), 15-Word Learning Test (24), Benton's Facial Recognition Task (25), Figure Detection 'Test (26), Verbal Fluency Test (26), and the Puncture Test (27). 


\section{Neuropsychological testing}

In the current investigation neuropsychological tests that have proven to be sensitive in the detection of cognitive impairment due to soccer were used $(1,12)$. Fach participant in this stady received a battery of neuropsychological tests that were administered by a trained psychometrician. The interview was performed by a qualified neuropsychologist. All tests were administered according to standardized instructions and procedures. The test data were scored by a qualified neuropsychologist who was blinded to the status of the participants.

The neuropsychological test battery included the following: Raven Progressive Matrices Test (RPM) (15), Wisconsin Card Sorting Task (16), Paced Auditory Serial Addition Task (PASAT); slowest version) (17), Digit Symbol Test (18), Trailmaking A and B (19), Stroop test (20), Bonrdon-Wiersma Test (21), subtests of the Wechsler Memory Scale (WMS; Associate Learning (all scores added), Logical Memory, and Visual Reproduction) (22), Complex Figure Test (Copy, Immediate Recall, and Delayed Recall) (23), 15-Word Learning Test (24), Benton's Facial Recognition Task (25), Figure Detection Test (26), Verbal Fluency 'Test (26), and the Puncture Test $(27)$.

\section{Statistical analysis}

The association of headers and soccer related concussions with the test scores was simultaneously determined, using a multivariate linear regression model. With this model their regression coefficients and one-tailed p-values. were determined, adjusting for age, the level of education, alcohol intake, the number of general anaesthesias and the number of concussions not sustained in soccer.

\section{Results}

\section{Population Characteristics}

The characteristics of the soccer players are shown in "Table 1. Most of the professional players showed a high education level: level $5(44 \%)$, level $6(41 \%)$, level $7(15 \%)$. The studied cohort consisted of forward players $26 \%)$, midfield players $(40 \%)$, defense players $(32 \%)$ and $2 \%$ of the players were goalkepers. Nine players (11\%) incurred concussions unrelated to soccer in a liferime. The median of concussions sustained in professional soccer is 1 and the professionals reported a median of 500 headers in a single season. The number of headers and the number of soccer related concussions showed a low correlation (Spearman's rank correlation $=.18$ ). 
"Table 1 Characteristics of 84 professional soccer players.

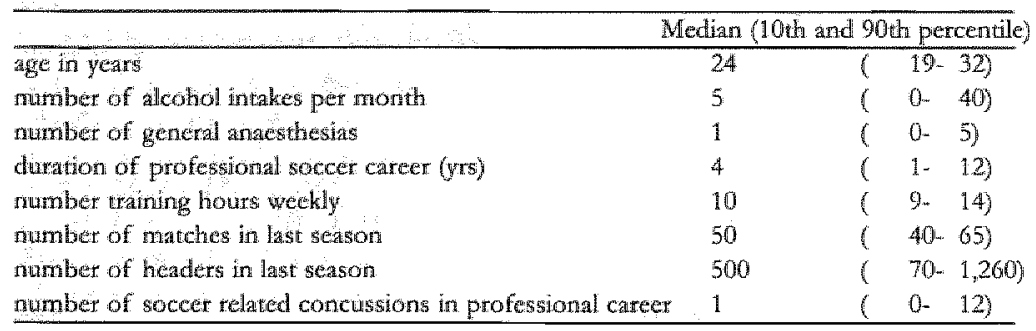

\section{Neuropsychological Testing}

In table 2 the results of the regression analysis are shown for the associations with one-tailed p-values $<0.05$ only.

Headets: The number of headers was inversely related to scores on the Complex Figure Test STM $(p=0.02)$ and LTM $(p=0.01), 15$ Word Learning Test $(p=0.03)$ and Trailmaking $A(p=0.048)$

Concusions:'The number of concussions was inversely related to scores on: Complex Fugure Test Copy (0.01), Facial Recognition Test (0.04) and Bourdon-Wiersma Test (0.04).

Table 2 Associations between neuropsychological test scores and the number of header's, soccer related concussions respectively Adjusted regression coefficients and their p-values are shown for the associations with a one-tailed p-value less than 0.05 only.

\begin{tabular}{|c|c|c|}
\hline & $\begin{array}{l}\text { Impaiment } \\
\text { pert } 1000 \text { headers } \\
(\mathrm{p}-\text { watues }\end{array}$ & $\begin{array}{l}\text { Impairment for each } \\
\text { soccer trelitted concussion } \\
\text { (p-yallue) }\end{array}$ \\
\hline Complex figune Trest SM & $-3.24 \quad(0.02)$ & \\
\hline Complex Pigune Test LTM & $(0.01)$ & \\
\hline Trail Making $A$ & $(0.048)$ & \\
\hline 15-Wond Levang Test & $0.03)$ & \\
\hline Complex frigune "Test copy & & $-0.11(0.01)$ \\
\hline Facial Recognion Test & & $-0.09(0.04)$ \\
\hline Bourdon Wiersma Test (sec) & & $+3.000(0.04)$ \\
\hline
\end{tabular}




\section{Discussion}

These findings suggests that neurocognitive impaiment in professional soccer is caused by two distinct mechanisms e.g, concussions and headers. It seems that concussions produce a more diffuse profile of brain injury whereas headers seens to deteriorate fronto-temporal brain functions.

In this study, several methodological precautions were taken to minimize interpretation mistakes. All the participants in this study were native Dutchmen who were educated according to the Dutch educational system, therefore eliminating misinterpretations caused by educational differences. In addition drug users and participants with medical conditions that might interfere with cognitive functioning were excluded from this investigation. To ensure reliability, tests and interviews were administered by a certified neuropsychologist and trained psychometricians. Confounding variables such as alcohol use, the number of concussions not sustained in soccer, the level of education and the number of general anaesthesias were adjusted using multivariate regression analysis.

The number of sports related concussions and the number of heaclers as used in this analysis are based on interviews with the soccer players and their physicians. "This way of collecting data is susceptible to misclassification.

We expect that this misclassification is nondifferential and conseguendy, the masclassification bias will be toward the null (28). This means that if there is an association of concussion and/or headers with cognitive functioning the coefficients as presented in table 2 are an underestimate of the real values.

The aim of this study is not to prove that soccer is dangerous, as we did in the two previous studies, but to explore whether soccer related concussion and/or headers contribute to neurocognitive dysfunction. Therefore we present the tesults with no adjustment of the signicance level for multiple endpoint testing.

Neuropsychological function loss associated to soccer related concussion involved tests measuring sustained attention, planning abbility and wisuo-perceptual functioning characteristic of diffuse brain injury.

Cognitive function loss associated to heading the ball involved tests measuring focused attention and verbal/visual memory capacity. "This is chatacteristic of fronto-temporal impairments as can be caused by linear movements of the head.

Our finding that CTBI in professional soccer is partly due to the number of concussions is in agreement with studies of concussion victims (29-31). The association between heading the ball and cognitive impairment is tarely documented in (sports) traumatic brain injury literature. Although, our results are in agreement 
with a recent MRI-study which compares MRI-abnormalities in soccer players and in American football players. Soccer players showed more abnormalities although both groups sustained the same number of concussions (7). The cumulative effect of headers can be an explanation for the differences found.

To limit the adwerse effects of heading the ball, precautionary measures need to be established. Coaches can be instructed to limit the number of heading drils in adults and headers can be banned in youth soccer.

\section{References}

Chapter 6

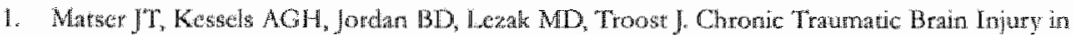
Profestional Socer Ptayers. Neurotogy 1998; $51: 791-796$

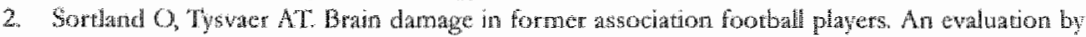

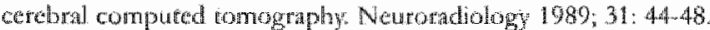

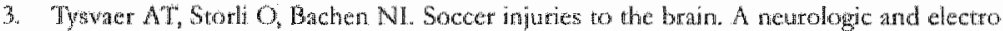

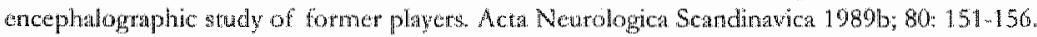

4. Tyswer AT, Lochen BA. Soccer injunes to the brain. A nemopsyctological sudy of former

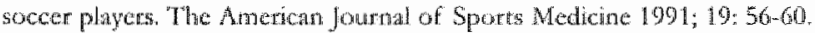

5. "Iyswer AT. Ilend and nech injures in soccer Inpact of minor trama. Sports Medicine 1902 ; 14: $200-213$

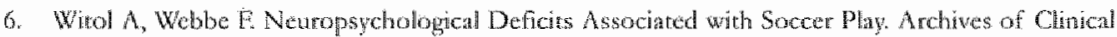
Neuropsychology $1994 ; 9: 1104-105$

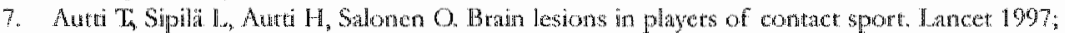
349: 1144 ,

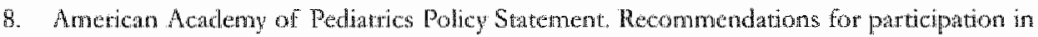
competitive sports. The Ptysictan and Sportsmedicine $1988 ; 16: 165-167$

2. Keily JP, Rosenberg JH. Diamosis and managenent of concussuon in sports. Neutology 1997 , $48: 5-580$.

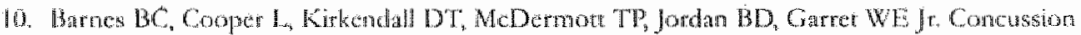
history in male and female socect players Mmerican Joumal of Sports Medicine 1998 ; 26.43948.

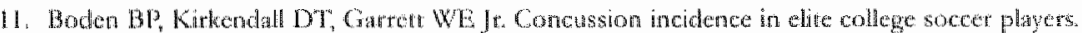
Ametrican fowrual of spore victicine 1998, 26:238-241.

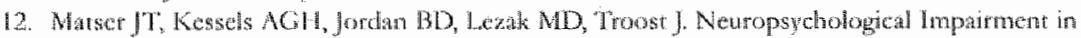

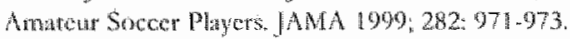

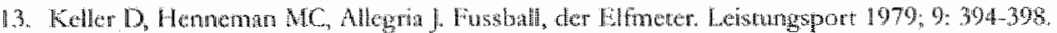

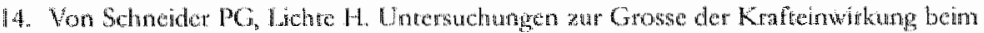

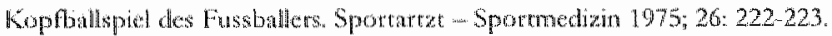

15. Raven JC. Guide to the Standand Progressive Marices. Eondon: Hilk Lewis, 1960.

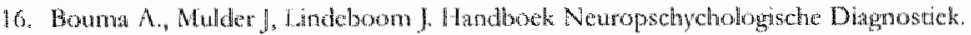

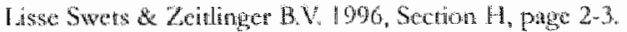

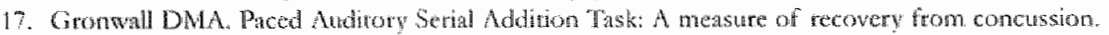
Perceptual and Moror Shills 1977; $44: 367-373$. 
18. Wechlser D. WAIS-R manual New York: The Psychological Corpotation, 1981.

19. Spreen $O$, Strass E. A compendium of neuropsychological tests. New York: Oxford University Press 1991.

20. Golden CJ. Stroop Color and Word Test. Chicago: Stoelling, 1978.

21. Van de Loo L. Enkele beschouwingen over de Bourdon Wiersma test Tipdschrift van de psychologische kring de Nijmeegse Uniwersiteit $1956 ; 2: 33-46$.

22. Wechsler D Wechsler Mernory Scale Manual. San Antonio: The Psychological Corporation, 1974.

23. Osterieth PA. Le test de copie d'une figure complexe. Archives de Psychologie 1944; 30: $206-356$.

24. Deelman $\mathrm{BG}_{n}$ Brouwer WH, van Zomeren AH. Functiestoornissen na trauma capitis. In: Jennekens-Schinkel $A_{\text {, ec }}$ al, Neuropsychologie in Nederland. Deventer: Van Loghum, Slaterus, 1980.

25. Benton AL, Hamsher $\mathbb{K}$, Varney $\mathrm{NR}_{*}$ Spreen O. Contributions to neuropsychological assessment. Newi York: Oxford University Press, 1983.

26. Luteyn E: Een nienwe werkorte GIT. Dutch Journal of Psychology 1966;2:675-682.

27. Wan der Vugt H. Lateralisaties van hersenfuncties: een neuropsychologyisch onderzoek naar de relatie tussen handvoorkeur en de relatie wan de talalfunctie. Lisse: Swets \& Zeidinger, 1979.

28. Sanford W. Applied linear regression. John Wiley Sons, New York. 1985 pP $76-78$.

29. Parasuraman $R$, Mutter $S A$, Molloy R. Sastained attention following mild closed head injury. Joumal of Clinical and Experimental Neuropsychology 1991; 13: 789-811

30. Gronwall D, Wrightson P. Memory and information processing alter closed head injury. Journal of Neurology, Neurosurgery \& Psychiatry $1981 ; 44: 889-895$.

31. Bohnen $N$, Twijnstra, $A$, Jolles J. Neuropsychological deficits in patients with persistent symptoms sicx months after mild head injury. Neurosurgery 1992; 30: 692-696. 


\section{General Comment}

\section{Summary Statement}

The serious questions about the cognitive consequences of (repeated) blows to the head due to sports activities remained not fully unanswered. In our studies, boxers and soccer players showed long-lasting neurocognitive changes (memory and planning impairments) due to concussive blows to the head. "This dissertation also demonstrated that acute symptoms resemble chronic sequels of concussion and that a number of repeated subconcussive blows to the head can cause detrimental effects concerning neurocognitive functioning. Looking at the number of brain injuties in soccer, a huge number of people suffer short or long tem effects, now and in the future.

\section{Test Selection}

After an ample study of the literature concerning mild traumatic brain injury (MTBI), we made a first selection of the test instruments, which were applicated in these patients. Tests were chosen which were validated and generally used in clinical practice. A third consideration was the limitation regarding time that was avallable for testing athletes. An exposure of 2 hours work for the athletes was the best what could be done. Computerised time saving versions of neuropsychological test are now under development and should result in increased access to testing. In addition, after talks with the researchers of the Pittsburgh Steelers project some tests were added in our battery (the Pitsburgh Steelers project was a large nation-wide prospective study in the USA in American football players in the beginning of the $90 \%$ s). In this way it was possible to compare our results with theirs.

In making choices between several tests for a new research field it is possible that we missed some opportunities to detect more defects in athletes. However, our American colleagues with, more or less, the same test batteries showed the same cognitive impaiments after fccurrent head/brain injurics in different kinds of athletic activities.

\section{Validity of our test results}

One important factor contributing to the validicy of neuropsychological testdata is the motivation of the persons taking the tests. The possibility of secondary gains, such as the lure of a big insurance setdement or the opportunity for early tetirement 
from unpleasant work may lead subjects to exaggerate deficits that are present or invent new ones. Although the issue of questionable motivation may be raised about any set of neuropsychological test data, it is typically not relevant when the subjects may actually comprise future opportunites by performing poorly. "This would appear to be the situation fot the athlete participants in these studies: a record of poor performance could reduce their value when competing for places on a team, and could follow them throughout their lives when they seek employment or to try raise their level of responsibility on the job.

However, should the question of motivation, as it relates to test validity, be raised, the group data provide keys to the validity of the athletes' neuropsychological test performances in several ways: (a) Some persons whose motvation is something other than the desite to do their besit perform poorly across the board (1), but such a test patrern in someone under the age of 50 with a good school or work history makes no neuropsychological sense and can be accounted for by no known neuropathologic entity (2). This was not how the athleres at risk for brain injury due to blows to the head performed, as all of their performances contained instances of average or better mental abilities. (b) Neuropsychologically naive persons are likely to believe that brain disorders will ustally cause memory problems and motor slowing, so that abnormally poor performances on tests that seem to measure memory ability and slowed responding on timed tests are also common features of malingering $(3,4)$. Yet the athletes at risk for head injury did not have problems with every kind of speeded test, and few displayed problems involving the memory system per se. (c) Perhaps the most telling characteristic of the test performances of these athletes was the way in which they sorted out into distinctive pattern reflecting the effect of headers and, in contrast, concussive effects. It would not have been possible for these neuropsychologically naive athletes to anticipate how or why to pretend they had incurred brain damage.

\section{Future Directions}

The Quality Standards Committee of the American Academy of Neurology (ANN) developed in 1997 a sideline evaluation designed for the immediate assesstzent of concussion in athletes. An objective quantifiable initial assessment of the injury is in our opinion essential for evaluating a player's readiness to return to competition (5). Close observation and reliable neuropsychological assessment of the injured athlete are critical to the prevention of a more serious injury and cumulative neuropsychological impairment. The AAN practice parameter and the studies shown in this dissertation both emphasise the importance of objectively assessing 
cognitive functioning as part of a screening procedure of athletes susceptive of mild traumatic brain injury and cumulations of these injuries.

\section{Recommendations}

In general, if an athlete has any symptoms related to MTBI, they should not be allowed to continue to play. Additionally, athletes with concussions should always be evaluated by a neuropsychologist prior to return to athletic play. Most importantly, any athlete who is symptomatic following a MTBI requires serial neuropsychologic evaluations till the athlete is performing on his own base-line level. Therefore we specifically promote the establishment of databases on contact and collision sport athletes. If similar neuropsychological instruments are utilised at all levels, longitudinal analysis of the test results for specific athletes will be possible as the athlete progresses from one level to the next when he/she incurred MTBI. This type of information would be particularly useful to athletes and physicians to assess the risk of future irijury and further difficulties.

\section{References}

General comment

1. Bernard IC, Houston W, Natoli L. Malingering on neuropsychological memory tests: potentill objective indicators. Joumal of Clinical Psychology 1993; 49:45-53

2. Lezak MD (1995). Neuropsychological Assessment. New York: Oxford University Press

3. Reitan RM \& Wolfson D. The question of validiry of neuropsychological test scones among headinjured litigants: Development of a Dissimulation Index. Archives of Clinical Neuropsychology $1996 ; 11: 573-580$

4. Sweet J], Wolfe P, Sattherger E et al, Further investigation of traumatic brain injury versus insufficient effort with the California Verbal Learning test. Archives of Clinical Neuropsychology 2000; 15: 105-113.

5. Puthinson D. Fivaluating cerebrall concussion. Surg Neural 1996; 45: 459.462, 


\section{Summary}

The researches which are described in this thesis, started about ten years ago. The main question was: do athletic activities cause cognitive impairment and can this be detected by neuropsychological research. Moreover, can sports specific conditions be linked with this impairment.

At the beginning of our researches there was little to no literature that could give us an idea about the brain clamages and the gravity of these damages which were caused by sports. Sport neurological subjects were not presented at congresses and/or symposiums until the beginning of the nineties. The interest in this subject has grown because of the attention that the media paid to some fatal sport accidents and to the deplorable condition some famous athletes were in after their sport career. Politics got interested in the subject and money was invested in research. At the moment thete is data concerning the percentages of brain damage in sports such as soccer, American football, ice hockey and rugby, and because of the increasing number of publications, it is becoming clearer that brain damage often causes permanent symptoms. In response to this the American Academy of Neutology (AAN) issued recommendations in 1997 to protect athletes against (cumulative) brain damage caused by sports. Since 1995 the AAN also organizes a sportsneurological congress ewery year in which numerous researches concerning damages of the central and peripheral nerve system are presented, and since 1995 the yearly conferences of the European Neurological Society (ENS) also present sportsneurological subjects.

Numerous (top-class) athletes consisting of boxers, amateur and professional soccer players, swimmers and middle distance runners participated in the researches described in this thesis. They were interviewed extensively and underwent extensive neuropsychological testing. The aim of the interview was to document factors that could be related to the gravity and the frequency of the sustained brain injuries (including the number of concussions, the frequency of matches and practices, and the number of traumas). The factors that are not related to sports but that could have a negative effect on the brain functions (such as concussions sustained outside the practice of sports, number of anaesthesias, diseases, educative/wage forming status etc.) were also documented. The neuropsychological tests were considered to be able to objectify mental changes due to brain damage. 
Chapter 1 describes the epidemiology concerning brain danage caused by boxing, soccer and sports in general. Furthermore the mechanical factors that can lead to brain damage and the physiological and neurochemical processes, which can be observed in these damages are described. Raring scales to determine the gravity of brain damage are also shown and discussed. Extensive attention is paid to the symptoms of a concussion and how concussions can be rated in measurements of gravity. Furthermore the cumulative effects of concussions and the risks of metabolic changes in the brain when sustaining cumulative brain damage are discussed.

Chapter 2 describes a study, which was conducted with the cooperation of 66 amateur boxers. Thirty-eight boxets were interview and tested neuropsychologically before and after a boxing match and 28 boxers were interviewed and tested neuropsychologically befote and after a practice task (without head contact). The boxers who had boxed a match performed less well on the memory, planning and attention tasks than the boxers who had practiced without head contact. Especially the combination weight class (the heavier the boxer), the number of blows to the head and knockouts appeared to correlate negatively with the memory and planning performance.

Chapter 3 describes a study conducted with the participarion of 49 amateur boxers who were classified in three groups according to their boxing experience (new members, 5 to 15 matches and more than 30 matches $\rangle$. All of them were interviewed and underwent neuropsychological testing in order to find out whether there was a difference in the neurocognitive functioning. The boxing experience had a negative influence on memory and attention. These attention disorders can be explained by the so-called "starting problem". A starting problem is a relative inativity while commencing a mental action, a characteristic of frontal patients as well as paticnts with brain damage in general.

Chapter 4 describes a study in which the neurocognitive functioning of 33 amateur soccer players was compared with that of 27 controls (swimmers and athletes). All of them were interviewed extensively and they all underwent neuropsychological resting. The test results of the two groups were compared, cortected by age, education, anaesthesias and alcohol. The soccer players preformed less well on the memory and planning tasks. Concussions were reported relatively ofter with the soccer players. Fifty per cent of the amateur soccer players had sustained one of 
more concussions during a match or during practice. The concussions appeared to correlate negatively with the memory takss. Thirty-nine per cent of the amateur soccer players performed under the norm on the planning tasks, in comparison, only 7 per cent of the controls performed under the norm.

The results of the researches suggest that practicing amateur soccer can be risky with regard to sustaining mild chronic brain damage. Especially the contact traumas (concussions) that occur during soccer matches and practices seem to cause neutocognitive problems in anateur soccer players.

Chapter 5 describes a research conducted on 53 professional soccer players who were compared to 27 controls (swimmers and middle-distance runners). All of them were interviewed extensively and underwent neuropsychological testing. The test results of the two groups were compared, corrected by age, education, anaesthesias and alcohol. In comparison with the controls, the professional soccer players performed less well on the memory, planning and visual perceptual tasks.

Of the professional soccer group 54 per cent of the participants had sustained one or more concussions during a soccer match and an average of 800 as registered per season. The number of headers and concussions related negatively to memory, planning and visual perceptual performances. The freld position (defenders/strikers were compared with midfielders/goalkeepers) was also a factor that correlated negatively with performances on visual perceptual and memory tasks.

The results suggested that practicing professional soccer has a negative influence on memory planning and visual perceptual performances. A dose-response relation was ascertained between these functions and the number of headers and concussions, Even though the neutocognitive damages are milder than the shortages observed in boxing, it could be concluded the preventive measures are needed to protect soccer players against brain injuries.

Chapter 6 describes a study among 81 professional soccer players in which it was examined which part of the neurocognitive damage can be ascribed to headings and which part can be ascribed to concussions. This was done by a simultaneous analysis of the role of both factors. There was a low correlation between the number of headings and the number of concussions. Neuropsychological function loss associated to soccer related concussion involved tests measuring sustained attention, planning abbility and visuo-perceptual functioning characteristic of diffuse brain injury.

Cognitive function loss associated to heading the ball involved tests measuring 
focused attention and verbal/xisual menory capacity. This is characteristic of fronto-temporal impairments as can be caused by linear movements of the head.

Thus, headers and concussions seem both to be risk factors for neurocognitive impairment.

From the results of the 5 demonstrated studies it can be concluded that boxing as well as soccer leads to relevant neurocognitive changes. It can be adwised, following the guidelines drawn up by the AAN in 1997, to examine contact and collision sport athletes neurpsychologically every year. Through this the athlete can compare oneself and stop in time after detection of a cognitive decline. It can also be advised to let athletes undergo a simple neuropsychological test following a head injury. After showing dewiant test scores a mandatory rest of at least one week without symptoms is recommended. 


\section{Samenvatting}

Ongeveer 10 jaar geleden begonnen wij met de voorbereidingen eerste instantie stelden we ons de vraag of de symptomen van hersenletsels die werden weroorzaakt door sportbeoefening aangetoond konden worden middels neuropsychologisch onderzoek. Ook waren we geinteresseerd of sportspecifieke condities gerelateerd konden worden aan neuropsychologische afwijkingen en of het mogelijk was dosisrespons relaties aan te tonen.

Bij het begin wan de onderzoekingen was nagenoeg geen literatuur voor handen om ons een beeld te kumnen vormen van de hersenletsels en de ernst van deze letsels die werden veroorzalakt door sportbeoefening. Momenteel zijn gegevens bekend betreffende de hersenletsel percentages bij de 'grote' sporten zoals voetbal (soccen), American football, ijshockey en rugby en wordt het steeds duidelijker door een toenemend aantal publicaties wat de neurocognitieve veranderingen zijn die hersenletsels kumnen weroorzaken. Ook heeft de American Acadeny of Neurology (AAN) in 1997 preventieve aanbevelingsmaatregelen uitgevaardigd om aderen te beschermen tegen cumulatieve hersenschade door sportbeoefening. "Tevens wordt sinds 1995 jaarlijks een sportneurologisch congres georganiseerd waarbij tal van onderzoeken worden gepresenteerd betreffende letsels aan het centrale en perifere zenuwstelsel veroorzaakt door sportbeofening. Ook bij de jaarlijkse confurenties van de European Neurological Society (ENS) staan sinds 1995 elk jaar sportneurologische onderwerpen op het programma.

Aan de onderzoeken zoals beschreven in dit proefschrift hebben tal van (top)sporters meegewerkt waaronder amateurboksers, amateur- en professionele voetballers, zwemmers en atleten. Bij allen die hebben geparticipeerd, is een uitgebreide anamnese en een neuropsychologisch onderzoek afgenomen. De anammese had tot doel factoren te documenteren die een relatie konden hebben met de ernst wan de neuropsychologische afwijkingen. Hierbij kan gedacht worden ann het aantal hersenschuddingen opgelopen bij trainingen of wedstrijden, de firequentie van wedstrijden en trainingen, en bij voetballers het aantal kopballen. Ook had de anamnese tor doel factoren te verzamelen die van invloed zijo op de mentale status van de sporters zoals het aantal hersenschuddingen opgelopen buten de sportbeoefening, het aantal narcose's, de doorgemaakte ziekten en de opleiding. $\mathrm{Bij}$ alle onderzoeken is in grote lijnen gebruik gemaakt wan dezelfde neuropsychologische tests. De neuropsychologische testbatterij was door de 
onderzocksgroep na literatuurstudies dusdanig samengesteld dat deze in staat geacht moest worden om veranderingen yan mentale prestaties door hersenletsels te kunnen objectiveten.

Hoofdstuk 1 beschrijft de epidemiologie betreffende hersenletsels veroorzaakt door sport met name boksen en wotbal. Verder worden mechanismen beschreven die leiden tot hersenletsels en wordt aandacht besteed an fysiologische en neurochemische veranderingen door voornoemde letsels. Classificatieschalen om de ernst wan hersenletsels te beoordelen worden getoond en besproken. Uitgebteide aandacht wotdt geschonken aan de symptomen wan een mild traumatisch hersenletsel en hoe deze letsels in te delen in mate van ernst. Verder worden cumulatieve effecten wan mild traumatische hersenletsels besproken in de acute en chronusche fase.

Hoofdstuk 2 beschrijft een studie die verricht is bij 66 amateurboksers. Achtendertig boksers die een wedstrijd boksten en 28 boksers die een fysieke taak uitwoerden werden neuropsychologisch getest voor en na de wedstrijd trespectievelijk na de fysieke taak. Participanten met leerstoornissen, een alcoholconsumptie van meer dan 5 eenheden per week, soft- en harddruggebruikers en participanten met een medische aandoening die het cognitieve functioneren kon benadelen werden uitgesloten van het onderzoek. De mediaan van het antal treffers op het hoofd tijdens wedstrijden was 8 en $35 \%$ van de boksers incasseerden meer dan 10 treffers per wedstrijd. Dertien procent van de wedstrijden eindigden in een knock out. De voor-na testscores tussen de beide groepen werd vergeleken en gecontroleerd werd voor leeftijd, opleiding, niveau van boksklasse, gewricht en tijdsinterval na de wedstrijd. Boksers die een wedstrijd hadden gebokst verschilden van de controles op plannings-, geheugen en andachtstaken. Uit de groep die een wedstrijd gebokst hadden bleek dat gewicht in combinatie met het antal geincassecede treffers een negatieve correlatie roonde met het plannings-en het visueel herinnetingsvernogen. Knock-outs reduceerden het antal elementen dat gereproduceerd kon worden op een verbale leertaak. Geconcludeerd kon worden dat het participeren aan bokswedstrijden acute neurocognitieve veranderingen veroorzaakt.

Hoofdstuk 3 beschrijft wen studie die verricht is met medewerking van 33 amateurboksers. Zeventien van de boksers hadden meer dan 30 wedstrijden gebokst, 16 boksers hadden tussen de 5 en 15 wedstrijden gebokst. Ook participeerden 16 personen die geen wedstrijd gebokst hadden. De drie groepen waren gematched op 
leeftij, etniciteit, opleiding en lichamsgewicht. Bij allen werd een interwiew en een neuropsychologisch onderzoek afgenomen. Tussen de boksers die meer dan 30 wedstrijden hadden gebokst en de overige boksers werd een verschil geconstateend betreffende het onthouden van complexe geometrische informatie op zowel de korte en lange termijn. Op eenvoudige geheugentaken werd geen verschil geconstateerd. Ook op getichte aandachtstaken en kleurbenoemingstaken werd een significante relatie met het aantal wedstrijden aangetoond. De gegevens suggereren dat amateurboksers met een hoge bokservaring gehinderd worden doof aandachtsstoomissen en visuele geheugentekorten.

Hoofdstuk 4 beschrijft een studie die is uitgevoerd bij 33 amateurvoerbalspelers en 27 controles (zwemmers en atleten). De voetballers waren afkomstig van 3 complete voetbalelftallen en de controles waren middenafstandslopers ( 2 complete atletiek teams) en zwemmers ( 1 compleet team) Van allen werd een uitgebreid interview en 27 neuropsychologische testen afgenomen, die geclusterd werden in 8 neurocognitieve functiegroepen.. De voetballers verschilden niet van de controles betreffende leeftijd, opleidingsniveau en aantal narcose's. Wel gebruikten de voetballers meer alcohol. Ook na correctie voor deze factoren werden verschillen in neurocognitief presteren tussen voetbalspelers en controlles geconstateerd. Dit betrof de planningscapaciteit (coördinatie van het denken) en de inprentingscapaciteit (het onthouden van zowel verbaal als visucel materiaal).

Hersenschuddingen werden relatief vaak gemeld in de voetbalpopulatic. Vijftig procent van de amateurvoetbalspelers had een of meerdere hersenschuddingen opgelopen tijdens het spel cq. de training. De hersenschuddingen bleken negatief te correleren met testscores behaald op werbale en visuele geheugentaken.

De onderzoelksbevindingen suggereren dat het spelen van amateurvoetbal risicovol kan zijn wat betreft het verwerven van mild traumatisch hersenletsel. Vooral de contacttrauma's (hersenschuddingen) die tijdens het voetbalspel en trainingen worden opgelopen lijken de neurocognitieve problemen bij amateurvoetballers te veroorzaken.

Hoofdstuk 5 betreft een onderzoek uitgevoerd bij 53 professional voetbalspelers die werden vergeleken met 27 zwemmers en middenafstandslopers van Olympisch niveau. Al de participanten werd een uitgebreid interview en een neuropsychologisch onderzoek afgenomen. De profvoetballers verschilden niet wan de controles wat betreft het aantall hersenschuddingen wat buiten de sport was opgelopen. De voetballers hadden een hogere opleiding en waren vaker onder 
natcose geweest dan de controles. Geen wan de profwotballers gebruikten soft cq. harddrugs. In de profwoetbalgroep had 54\% wan de participanten een of meerdere milde hersenletsels opgelopen tijdens het woetbalspel. Gemiddeld werden 800 kopballen per seizoen genoteerd en werden gemiddeld 50 wedstrijden per seizoen gespeeld.

In vergelijking met de controlles toonden de profwoetballers cen significant verschil betreffende scores op verbale en visuele geheugentaken, planningstaken en visuoperceptuele tests, ook na correctie voor alcoholgebruik, aantal narcose's, opleidingsniveau en hersenschuddingen opgelopen buiren ther voetbal. Het aantal kopballen en milde hersenletsels beïnvloedden negatief de prestaties op verbale-en visuele geheugentaken, planningstaken en visuo-perceptuele tests. Veldpositie (verdedigers en spitsen wergeleken met middenveldets) was eveneens een factor die negatief associectde met scores op visuo-perceptuele-en geheugentaken.

De resultaten suggereren dat door het spellen van profwoetbal neurocognitieve functies verslechteren. Om deze negatieve effecten te beperken kan base-line neuropsychologisch onderzoek en neuropsychologisch onderzoek direct na het letsel (side-line testing) aangeraden worden, zoals gepropageerd door de American Academy of Neurology (AAN, 1997).

Hoofdstuk 6 betreft cen studic bij 81 profvoetballers waarbij het effect van koppen en hersenschuddingen op het neurocognitieve functioneren afzonderlijk is bekeken. Uit de analyse bleek dat er geen correlatie was tussen kopballen en het antal hersenschuddingen. Hersenschuddingen die waren opgelopen tijdens het spelen van voetbal bleken planningscapaciteit, visuo-spatieel vermogen en het vasthouden van de aandacht negatief te beïnvoedden. Een toenemend aantal kopballen bleck het vermogen om de aandacht te richten en visuele en verbale geheugenprestaties te benadelen.

De resultaten suggereren dat hersenschuddingen neuropsychologische afwijkingen verootzaken die duiden op ciffuus hersenletsel en de afwijkingen door het antal kopballen op tronto-temponale letsels wijzen.

Uit de resultaten van de 5 gepresenteerde studies kan geconcludeerd worden dat boksen en voetbal een negatieve invloed hebben op neurocognitieve prestaties. Het is te overwegen om de richtlijnen zoals voorgesteld door de American Academy of Neurology (1997) in deze sporten toe te passen. 


\section{Dankwoord}

Dit dankwoord kan niet compleet zijn. De wijf onderzoeken, witgevoerd in een periode van 10 jaar, zijn een product wan de inspanningen van meer dar tweehonderd mensen. Het is ondoenlijk op deze plats iedereen persoonlijk te bedanken. Ik wil me dan ook op deze pagina beperken tot de onderzoeksgroep die actief bezig is geweest met de onderzoeken en het publiceren wan do onderzoeksgegevens. Ik kan slechts hopen dat ik al degenen, die nier vermeld staan, mijn dankbaarheid eerder al heb getoond.

Muriel Lezak, thanks for giving me the opportunity to look in the kitchen of a neuropsychology three star testaurant. You generously shared your spotight and afforded me the chance to be heard. Your wisdom, caring insight and direction led me to finish this dissertation. Your knowledge about neurocognitive and intellectual impairments after traumatic brain injury was a main source in understanding the brain-behavior relationships we observed in our studies. In coming with my family to Oregon you showed us amazing hospitality and also dazzling opportunities for neuropsychological assessment in athletes and brain injured people. You showed me the way of how to look at patients and the importance of kwalitative neuropsychological assessment. It was, and still is, a thrill to see you working with patients. I adapted your 'grandmother style of communication' in writing atticles and patient reports. It is important to demonstrate your thinking in a way that anyone can undierstand it, other than to write very unorganised complex material with an impact only for the "happy few". You taught me that questioning was a virtue, and that no questioning was either stupid or unworthy of an answer. Even beside out work as presented in the studies you were always available for advice and guidance. For me personally, you are a high walued mentor and I still remember our numerous conversations regarding neuropsychological and social topics. I will always adtapt the one liner: Let others be angty, this is a free country!

Jaap Troast, beste Jaap, ik zal het kort houden zoals je stijl het betaamd. Je hebt me een prachtige gelegenheid gegeven om in en academische context, met uitstekende mensen artikelen te kunnen schrijwen en om te promoveren. Na een middelbare schoolperiode ben ik op de Universiteit van Nijmegen 'thuis getromen' en begon mijn interesse voor de neuropsychologie en neuroanatomie te grocien. Wat ik geleerd heb in de afgelopen jaren is dat als men gemoviverd is om een bepaald onderwerp te beswderen men een 'eminence grise' nodig heeft die handvaten kan 
geven waar men zichzelf aan kan vasthouden. Dit voorkomt vroegtijdig uitglijden en men kan verder vooruit komen. Je hebt altijd vertrouwen in me gehad en ik zie je als een man die mij een enorme dưw wooruit heeft gegeven betreffende tal van studiegedachten en sociale aspecten. Jaap ook jij had een oneliner die ik met me mee zal dragen. Gelijk hebben is niet hetzelfde als gelijk kriigen!

Last but not at all least 'Mgr Alphonso' Fons Kessels, MD. Beste Fons, we hebben nu al ettelijke malen de bladen in de USA met verhalen over boksers en voetbalspelers 'bevuild" met onze 'maligne' idecën betreffende de neurocognitieve status van de sporthelden. Bij het allereerste contact met jou stelde je me gerust met een zwart-wit lollie waarvan ik nadien miljoenen heb verslonden. Als we eerlijk zijn Fons hebben we eigenlijk gewerkt voor maar een doel; sterven in een life uitzending van David Letterman.

Fons je bijdragen aan de verschillende onderzoeken zijn dermate dat zonder je inbreng geen presentaties in 'Neurology' en 'JAMA' zouden zijn. Je manier van werken, het geloof in eigen kunnen en het zeer nauwgezet reageren op de referenten en het analyseren wan wat de referenten willen, zijn de spil geweest waarop de publicaties en deze gehele dissertatie drijven. Fons je was in de vijf jaar dat we zeer intensief hebben samengewerkt een goede coach. Een goede coach bij bv het voetbal is iemand met 'fingerspitzen' gevoel, die een tactisch inzicht heeft en die zijn troepen op de goede momenten kan motiveren. Ik denk dat je daar in de vijf afgelopen jaren wonderwel in bent geslaagd. Werken met jou is een leerproces waarvan ik hoop dat het na voltooien van dit proefschrift doorgaat. Fons jouw oneliner: elke Nobelprijswinnaar heeft statistische lijken in de kast die er absoluut niet uit mogen vallen. Fons, bedankt voor alles and for being a friend! 